\title{
Numerical Simulation of an on-Grid Natural Gas PEMFC - Solar Photovoltaic Micro CHP Unit: Analysis of the Energy, Economic and Environmental Impacts for Residential and Industrial Applications
}

\author{
Renato de Oliveira Gabriel ${ }^{1} \cdot$ Sergio Leal Braga ${ }^{1} \cdot$ Florian Pradelle $^{1}$ (1) $\cdot$ Eduardo Torres Serra $^{2}$. \\ Cesar Luiz Coutinho Sobral Vieira ${ }^{3}$
}

Received: 16 October 2020 / Accepted: 18 January 2022 / Published online: 15 February 2022

(c) The Author(s), under exclusive licence to Springer Nature Singapore Pte Ltd. 2022

\begin{abstract}
As global natural resources depletion and concern on emission of greenhouse gases intensify, the interest for low emission technologies and the use of renewable energy increased in the world. In this context, this paper aims to present an hybrid energy system for on-grid micro residential and industrial applications. The system is composed of a micro combined heat and power (CHP) unit, including a natural gas (NG) reformer coupled with proton-exchange membrane fuel cell (PEMFC), solar photovoltaic modules (PV) and a bank of batteries (B), connected to the grid through a bidirectional inverter. Different system configurations (PEMFC + PV + B, PEMFC + B, PEMFC + PV), with or without cogeneration of the heat from the CHP system, were investigated to calculate the required NG and electricity flows and assess the economic cost during 10 years of operation in an 2020-2040 horizon. The impact of fuel cell sizing and two electricity tariffs was also assessed for both applications. Afterwards, the cash flow in terms of net present value of a 20 years operation period was simulated within the Brazilian context, yielding estimated paybacks between 7 and 19 years for the simulated cases. Finally, an environmental impact analysis was carried out to investigate the total GHG emissions for some cases of interest in this work. The proposed system could reduce total emissions up to $31 \%$ when compared to the complete power and thermal supply by the Brazilian Electricity grid and natural gas heater The results showed that the proposed system were economically viable, relatively low-polluting and more efficient than traditional PV systems.
\end{abstract}

Keywords Combined heat and power (CHP) unit · Proton-exchange membrane fuel cell (PEMFC) - Solar photovoltaic $(\mathrm{PV})$ modules $\cdot$ Batteries $(\mathrm{B}) \cdot$ Natural gas $(\mathrm{NG}) \cdot$ Simulation

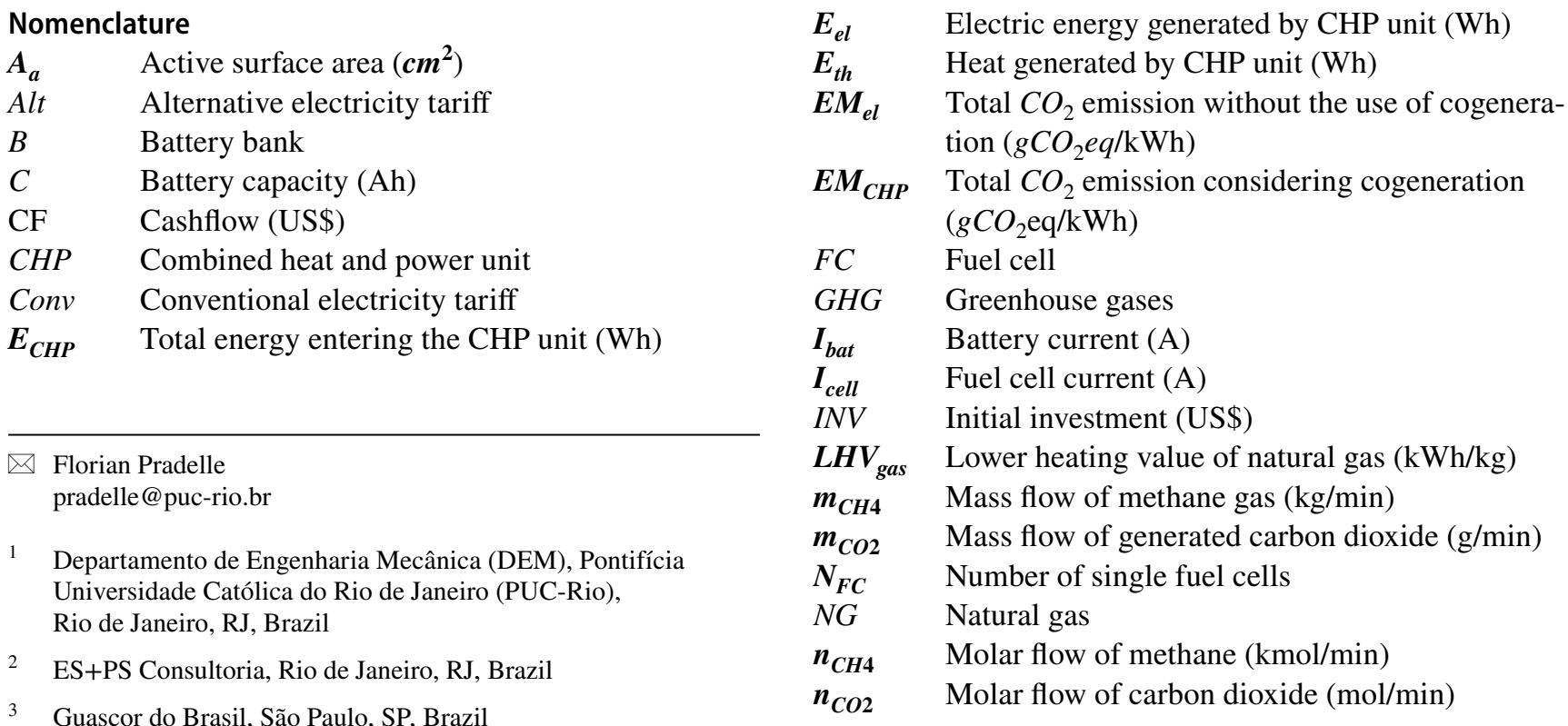




\begin{tabular}{|c|c|}
\hline$n_{H 2}$ & Molar flow of hydrogen $(\mathrm{kmol} / \mathrm{min})$ \\
\hline$N P V$ & Net present value (US\$) \\
\hline$M W_{C H 4}$ & Molecular weight of methane $(\mathrm{kg} / \mathrm{kmol})$ \\
\hline $\mathrm{MW}_{\mathrm{CO}_{2}}$ & Molecular weight of carbon dioxide $(\mathrm{kg} / \mathrm{kmol}$ \\
\hline $\boldsymbol{P}_{\boldsymbol{e l}}$ & Electric power $(\mathrm{W})$ \\
\hline$P_{t h}$ & Thermal power $(\mathrm{W})$ \\
\hline$P V$ & Photovoltaic panels \\
\hline$Q_{e}$ & Charge remaining in battery bank (Ah) \\
\hline$r$ & Interest rate $(\%)$ \\
\hline$S_{H_{2}}$ & Hydrogen stoichiometry \\
\hline$S O C$ & Battery state of charge (\%) \\
\hline$V_{\text {cell }}$ & Single fuel cell voltage $(\mathrm{V})$ \\
\hline$V_{\text {gas }}$ & Total natural gas consumption $\left(\mathrm{m}^{3}\right)$ \\
\hline$y$ & Time (years) \\
\hline
\end{tabular}

\section{Greek Letters}

$\eta_{e l} \quad$ Electric efficiency (\%)

$\eta_{\text {th }} \quad$ Thermal efficiency (\%)

$v_{\text {gas }} \quad$ Volumetric flow of methane gas $\left(\mathrm{m}^{3} / \mathrm{min}\right)$

$\rho_{\text {gas }} \quad$ Density of natural gas $\left(\mathrm{kg} / \mathrm{m}^{3}\right)$

\section{Introduction}

Electric energy demand is expected to increase $1.3 \%$ per year up to 2050 in non-OECD countries, according to the U.S. Energy Information Administration [44]. All sectors will be affected by the change, especially the residential sector due to the urbanization process and increasing population's purchasing power in developing countries [24]. This phenomenon has led to greater environmental concern in most countries, which have intensified the search for cleaner and more efficient energy generation sources, leaded by photovoltaic and wind power. Alongside with this tendency, more reliable energy distribution / transmission processes have become increasingly necessary. In this context, the distributed electricity generation system emerges as an effective solution. Several advantages, such as higher reliability of electricity supply and greater voltage stability in the grid, can be achieved with the distributed generation system. In the economic context, attention is given to the lower operating costs in transmission and distribution. Moreover, from the environmental point of view, the lower emission of greenhouse gases and the conservation of natural resources are potential benefits with the use of renewable sources [16, 23].

More recently, developing countries, especially India, Brazil and China, have also started to show significant participation in the adoption of the distributed generation system, driven mainly by greenhouse emissions reduction policies and diversification of their energy matrices. Solar photovoltaic (PV) generation is still the most prevalent in the distributed micro-generation sector due to the ease of installation, a large-scale world production and the rapid drop in the commercialization prices of photovoltaic modules (reduction of a factor of 100 between 1975 and 2015) [31]. In spite of its great advantages in both economic and environmental viewpoints, high area is required for modules installation which and its high dependence on the reverse metering factor (utilization factor of corresponding energy generation exported to the grid) may limit its applications in large cities.

Nowadays, the search for energy sources with lower pollutant emissions than traditional diesel and oil related technologies, such as natural gas, is being considered by many experts as the transition solution between more polluting energy sources (as oil and coal) and the purely renewable generation [24]. Thus, the combination of intermittent energy sources with storage devices and additional sources with the use of natural gas may become the ideal solution for the future of distributed generation, constituting hybrid energy systems.

Among the energy conversion technologies, fuel cells have the desired potential for hybrid systems integration as they present high energy efficiency, relatively low pollutant emissions and allow for cogeneration as a consequence of high temperature stack operation $[1,12,15]$. Many studies are been developed in this area, aiming for hybrid systems optimization and economic evaluation. Rekioua et al. [37] presented a detailed review on hybrid systems configurations with proton-exchange membrane fuel cell (PEMFC) and demonstrated the feasability of a PEMFC+PV system with hydrogen storage for small applications. Maclay et al. [32] studied a PV system coupled with reverse fuel cell, battery bank and ultra-capacitors as storage components. An economic assesment was performed to identify the best combination in terms of efficiency and cost. The work concluded that the integration of battery banks and fuel cells provided benefits in both energy and economic viewpoints in comparison with each technology separately and that ultracapacitors were unsuitable for the proposed application because of their low energy density. Later, Maclay et al. [33] carried out and experimental study to investigate the dynamic behavior of the same system under rapid changes of load demand. Their work focused on specifying design limitations for the fuel cells, battery bank and electrolyser for such systems, giving emphasis to components sizing and operating restrictions. Ozgirgin et al. [36] performed a simulation analysis on an integrated on-grid hybrid system with PV pannels, PEMFC and battery bank to supply a small residence in the proximities of Ankara (Turkey). They studied the impact of the seasons and the potential for cogeneration. The results showed that during the warmer seasons, the proposed system could successfully generate all thermal and electric power load demands, exporting extra energy to the grid. However, during winter time, much more area 
for PV modules installation was needed. An energetic and exergetic study of a hybrid system with PEMFC and solid oxide fuel cell (SOFC) fed with natural gas (NG) was conducted by Barelli et al. [7] for small residential applications. Several parameters such as fuel cell temperature and pressure operating conditions were evaluated as to their impacts in each proposed configuration performance. Zuliani and Taccani [46] compared the differences in electric and thermal efficiencies of low and high temperature PEMFC systems for small applications ( $1 \mathrm{~kW}$ electrical output). It was found that the total system efficiency (26\% to $34 \%$ ) was higher than the general efficiencies of LTPEM type fuel cells systems found in the literature for this power specification. Di Marcoberardino and Manzolini [14] assessed the economic feasibility of a $5 \mathrm{~kW}$ PEMFC system fed with NG and compared the results with traditional CHP systems. The impact of NG composition and electric energy prices were evaluated in four countries of the European Union and always showed environmental benefit even if the system cannot be competitive even with subsidies from the governments. In the work of Inac et al. [25], the energy and exergy efficiencies of a system consisting of a SOFC unit fed by three different methods was studied. First, PV modules were used to provide electric energy to an electrolyser, which then produced hydrogen for the SOFC. Second, an anaerobic digester supplied biogas for use in the fuel cell and, finally, a local distribution network provided natural gas (methane) directly to the SOFC. Results proved that the third method showed better overall energy and exergy performance, followed by the second and first methods, respectively. Additionally, the highest exergy destruction occurred in the first method, followed by the second and third methods as well. Ahmadi et al. [4] investigated the influence of several operational parameters on the energy and exergy efficiencies of a system involving a SOFC with cogeneration. The system consisted of the combination of electrical output from the fuel cell with another heat and power combined cycle, composed of two turbines (high and low pressure) and a DHW (Domestic Hot Water) unit to supply a thermal demand. An improve in overall energy efficiency from $47.78 \%$ (only electric output from SOFC) to $60.05 \%$ (SOFC with a combined cycle) was observed. Moreover, the sensibility analysis showed that an increase in fuel utilization factor enhaced even more the energy and exergy efficiencies, while an increase in electric current density of SOFC produced the opposite effect. Finally, Azizi and Brouwer [6] investigated severall methods for controlling a SOFC-GT (SOFC coupled with gas turbine) system in different configurations and compared multiple control strategies as for their impacts in energy efficiency and $\mathrm{CO}_{2}$ sequestration by means of a sensibility analysis. The authors found that more robust control algorithms were requested in cases of variable turbine shaft speed over stationary applications, requiring additional parameters to handle pressure fluctuations in the SOFC stack. Additionally, a literature review carried out by the authors showed that other variables as fast electrical and thermal transients, compressor stall / malfuntioning, cell degradation and fuel starvation remain as critical parameters for dynamic operation of physical SOFC-GT, requiring further research on this area. In addition to the reported studies, several other approaches for investigating hybrid system's operation can be found in literature with the use of HOMER [13, 38, 43], Aspen Plus ${ }^{\circledR}[7,14,46]$, LabVIEW, Matlab / Simulink routines $[30,32,33,37]$ and combination with $\mathrm{AI}$ (artificial intelligence) techniques $[3,35]$.

In this context, this paper presents a numerical simulation in Matlab (version R2019b) of an hybrid system consisting of a $5 \mathrm{~kW}$ PEMFC unit combined with solar PV (multiple $245 \mathrm{~W}$ modules) and battery bank (parallel combination of $48 \mathrm{~V} / 100 \mathrm{Ah}$ batteries) for small on-grid residential and industrial applications in Brazil. Several system configurations with cogeneration possibility, two types of electricity tariffs (conventional (Conv.) and alternative (Alt.)) and two types of consumers (residential and industrial) were investigated to assess their impacts in system's operation, efficiency, economic analysis and GHG emission impact (in terms of $\mathrm{gCO}_{2} / \mathrm{kWh}$ ). The Bazilian natural gas market is currently under great transformation and development. The New Gas Market Program, announced in June 2019 by the Federal Government, has the main objective of creating a more dynamic and competitive market, ending the existing monopoly in the natural gas sector and implementing measures to increase competitiveness in all segments of the chain, from gas production, treatment, distribution and transportation. The national gas production is expected to more than double in a ten year's time, going from 124 million cubic meters in June 2019 to a total of 267 million cubic meters per day until 2032 and total cost reductions may reach $40 \%$ by the end of 2021 [10]. In that way, natural gas could effectively act as the transient solution between high pollutant energy generation systems and totally renewable systems (photovoltaic and wind) in Brazil and other countries, such as China and United States, that presently experience similar transformations in the NG market.

Therefore, the main contribution of this work is to provide a detailed analysis of such system considering the Brazilian scenario, assess its economic feasibility and compare total system's cost and cashflow analysis with conventional PV systems and direct electricity purchase from the grid. Additionally, the potential benefits evaluation in terms of equivalent $\mathrm{CO}_{2}$ emissions reduction compared to the total energy supply from the Brazilian electricity grid and natural gas combustion (thermal demand) was also another original aspect of this study. 
Fig. 1 Schematic representation of the modeled system

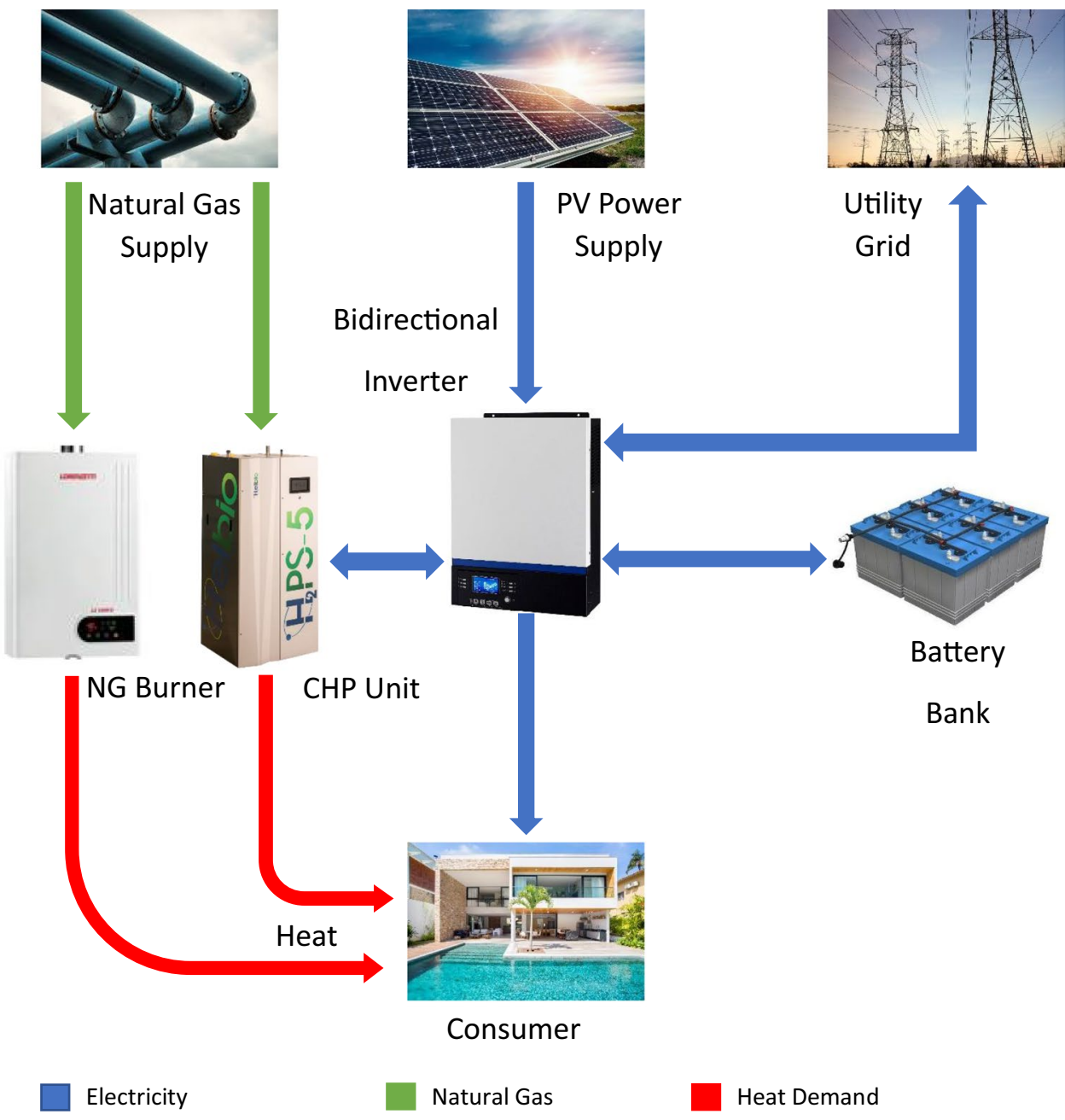

\section{Methodology}

\section{Mass and Energy Balances}

The proposed on-grid system consists of a $5 \mathrm{~kW}$ micro combined heat and power CHP unit (NG reformer + PEMFC), 245 W PV pannels and a battery bank (B) (parallel conection of multiple $48 \mathrm{~V} / 100 \mathrm{Ah}$ single batteries), connected to a bidirectional inverter to provide electric energy to a consumer in the AC terminal. On-grid distributed electricity generators are a complex system in which the relationship between the observed parameters. Then, the elaboration of a control action should be carried out on the basis of data on the current state of the object of control in order to guarantee that energy demand and future needs of power from the consumers will be provided and aim the lowest cost for electricity $[2,40,45]$. Then, the PV array works as the primary source of energy during the day, charging the battery and exporting extra energy production to the grid. When demand exceeds total generation within the system, PEMFC + NG reformer unit provides electrical output to sustain the deficit just after a brief warming-up period of $30 \mathrm{~min}$, during which it consumes $550 \mathrm{~W}$ from the grid. Once power demand is too high, the system starts to buy electricity directly from the grid. While running on alternative tariff, the logic is similar with one exception. The batteries were forced to charge to its maximum state of charge just before $5 \mathrm{PM}$ and then fully discharge between $6 \mathrm{pm}$ and $9 \mathrm{pm}$, exporting large amounts of energy to the grid and generating lots of energy credits.

Furthermore, cogeneration can be achieved for supplying an additional thermal demand. As allowed by Brazilian legislation, extra electric energy production within the system is sent to the grid, generating energy credits for future use when demand exceeds total generation. The reverse metering factor used in this work was $100 \%$, according to Brazil's current scenario. Three climate options for photovoltaic power input has been considered, accounting for sunny, partially cloudy and cloudy days. Climate is randomly chosen in the simulation for each day. A schematic representation of the modeled system and the profile of consumers's electric demand are shown in Figs. 1 and 2, respectively. 


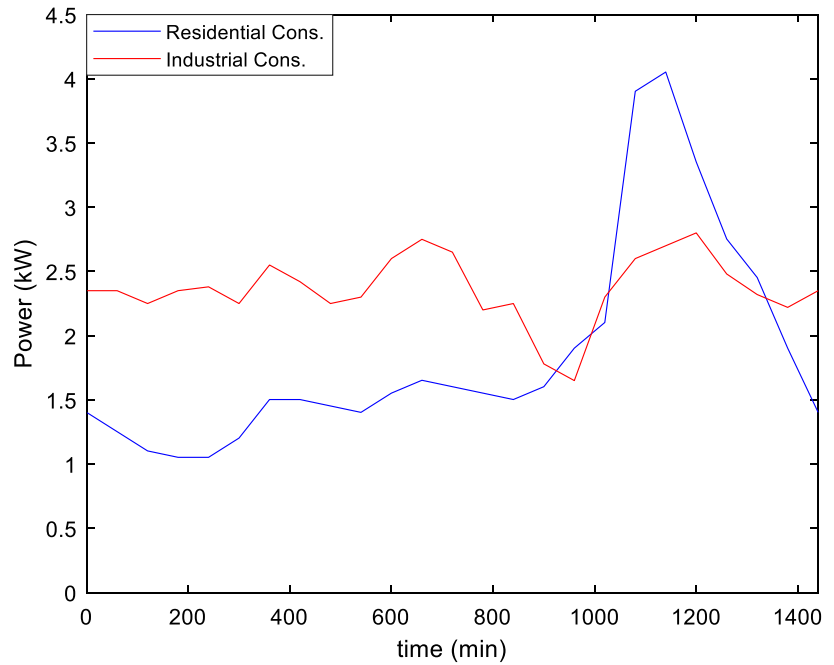

Fig. 2 Consumers power demand for one day [19]

As seen in Fig. 2, residential energy consumption is relatively low in the early hours of the day, having a peak demand between $6 \mathrm{pm}$ and $11 \mathrm{pm}$. On the other hand, the industrial load profile presents less fluctuation throughout the day.

Current in and out of the battery bank $\left(I_{b a t}\right)$, in A, is determined dividing electric power by the tension $(48 \mathrm{~V})$. State of charge (SOC) limits are fixed at 20\% minimum and $90 \%$ maximum. Later, total charge remaining in the battery $Q_{e}$, in A.h., and battery's state of charge are updated according to Eqs. (1) and (2), where $\Delta t$, in $\mathrm{h}$, is the interval time analysis (chosen equal to one minute) and $C$ is the total battery capacity, in A.h [28].

$Q_{e(t+1)}=Q_{e(t)}-I_{b a t} \Delta t$

$S O C=1-\frac{Q_{e}}{C}$

Next, Fig. 3 shows a schematic representation of the CHP unit, composed of natural gas reformer and PEMFC. The reformer consumes water and natural gas (assumed to be pure methane) and generates hydrogen for utilization in the PEMFC subsystem, which then produces electrical power output. As the reactions occur at high temperature, cogeneration with heat rejection from the PEMFC unit is achievable.

Molar flow of hydrogen going into the fuel cell $\left(n_{\mathrm{H} 2}\right)$ is given by Eq. (3) in $\mathrm{kmol} / \mathrm{min}$ [25]. Number of single cells within fuel cell stack $\left(N_{F C}\right)$ and active surface area $\left(A_{a}\right)$, required to calculate the current into a single fuel cell $I_{\text {cell }}$, in $\mathrm{A}$, were assumed as 75 and $200 \mathrm{~cm}^{2}$, respectively [11]. $F$ is the Faraday constant $(96.485 \mathrm{C} / \mathrm{kmol})$ and $S_{H_{2}}$ is the hydrogen stoichiometry (assumed equal to 1.00 in this study).
$n_{H 2}=60 \frac{S_{H 2} I_{c e l l} N_{F C}}{2 F}$

Then, molar flow of methane $\left(\mathrm{CH}_{4}\right)$ is defined as a quarter of the molar flow of hydrogen $\left(\mathrm{H}_{2}\right)(\mathrm{Inac} 2019)$ and total gas consumption $\left(v_{\text {gas }}\right)$, in $\mathrm{m}^{3} / \mathrm{min}$, within CHP unit is calculated in (4) by assuming $100 \%$ metane composition and standard ambient conditions. In (4), $m_{C H 4}$ is the mass flow of methane $(\mathrm{kg} / \mathrm{min})$ and $\rho_{\text {gas }}$ is the natural gas density $\left(0.76 \mathrm{~kg} / \mathrm{m}^{3}\right)$.

$v_{\text {gas }}=\frac{m_{C H 4}}{\rho_{\text {gas }}}=\frac{0.016 n_{H 2}}{\rho_{\text {gas }}}$

Finally, thermal power rejection $\left(P_{t h}\right)$, in W, caused by the exotermic reactions at high temperature operation of the fuel cell is given by (5) [11]. Electric $\left(\eta_{e l}\right)$ and thermal $\left(\eta_{t h}\right)$ efficiencies are calculated according to Eqs. (6) and (7) [11] and were found to be $51.2 \%$ and $48.8 \%$, respectively. $V_{\text {cell }}$ and $I_{\text {cell }}$ are the stack total voltage $(\mathrm{V})$ and current (A) through each single fuel cell.

$P_{t h}=N_{F C}\left(1.25-V_{\text {cell }}\right) I_{\text {cell }}$

$\eta_{e l}=\frac{1}{S_{H 2}} \frac{V_{\text {cell }}}{1.25}$

$\eta_{t h}=\frac{1}{S_{H 2}}\left(1-\frac{V_{\text {cell }}}{1.25}\right)$

Figs. 4 and 5 present a four-day operation analysis of system's operation for two residential consumers with conventional tariff. Figure 4 shows the power flow through system's components while Fig. 5 shows the grid consumption and banked credits. Power flow through each system component was determined via a control algorithm introduced in Appendix Fig. 12 for conventional tariff. Load demand and PV generation are always positive, while for the battery bank, utility grid and PEMFC unit, power can be positive or negative. Negative power represents battery charging, PEMFC warming up power consumption and grid export. On the other hand, positive power means battery discharging, PEMFC power production and grid import.

\section{Economic Study}

In order to evaluate system's feasibility and impact on each possible configuration $(\mathrm{FC}+\mathrm{PV}+\mathrm{B}, \mathrm{FC}+\mathrm{PV}$ and $\mathrm{FC}+\mathrm{B})$, an economic analysis was performed for both types of consumers in the Brazilian scenario. A total of ten PV pannels and three batteries were used for each consumer. Energy input operation tariffs for electric energy and natural gas in 2020 are chosen equal to the current cost in the city of Rio de Janeiro, Brazil (as shown in Appendix Table 12). Electric 


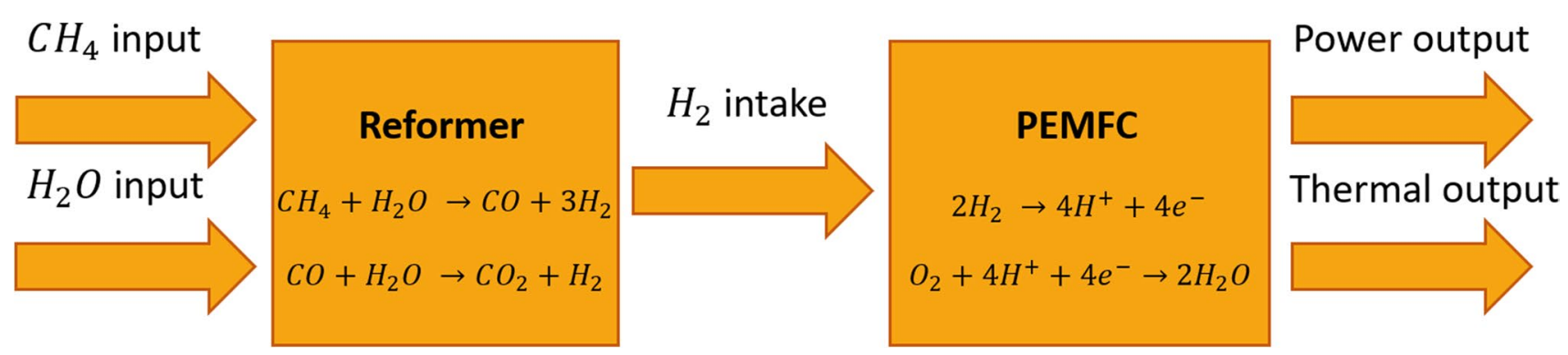

Fig. 3 Schematic representation of the CHP unit (PEMFC + NG reformer)

Fig. 4 Power flow through all system's components for a four days simulation
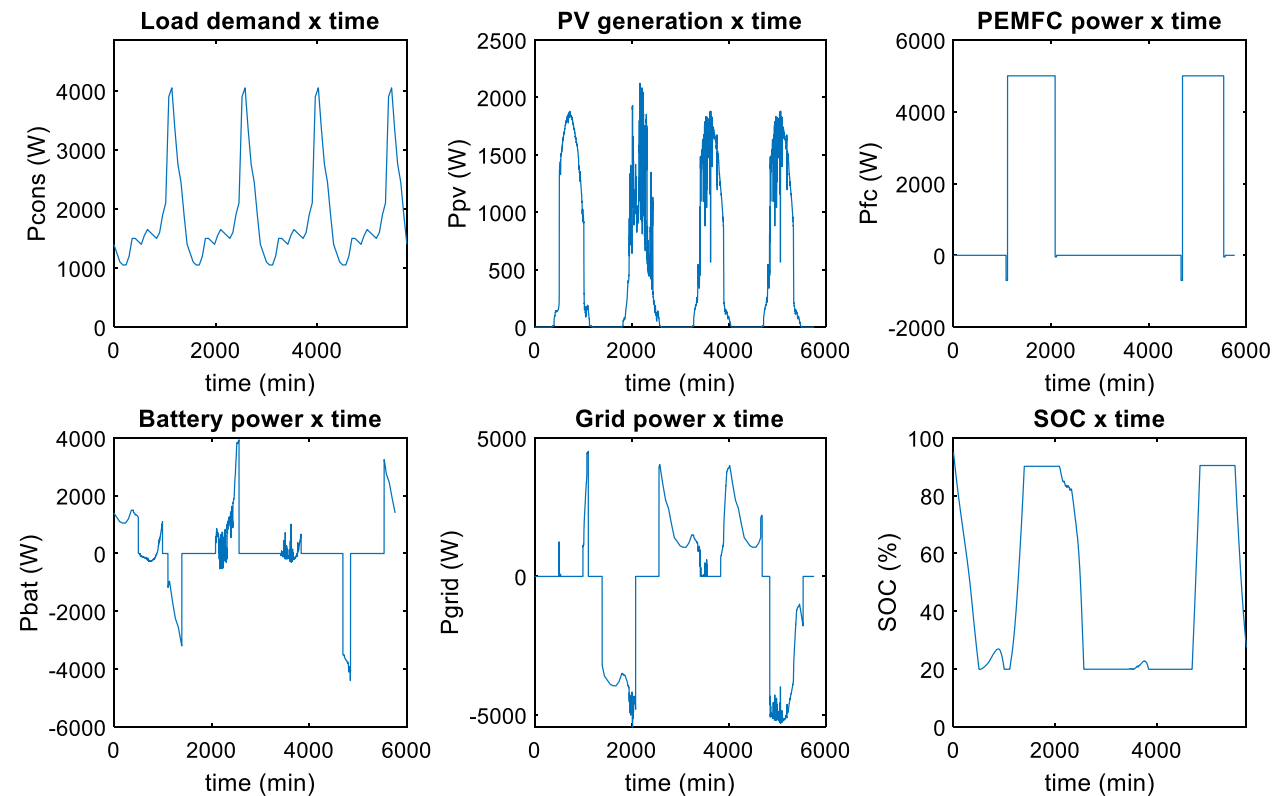

energy tariff was assumed to increase $2 \%$ above inflation per year against $0 \%$ increase in NG tariff after linear decay
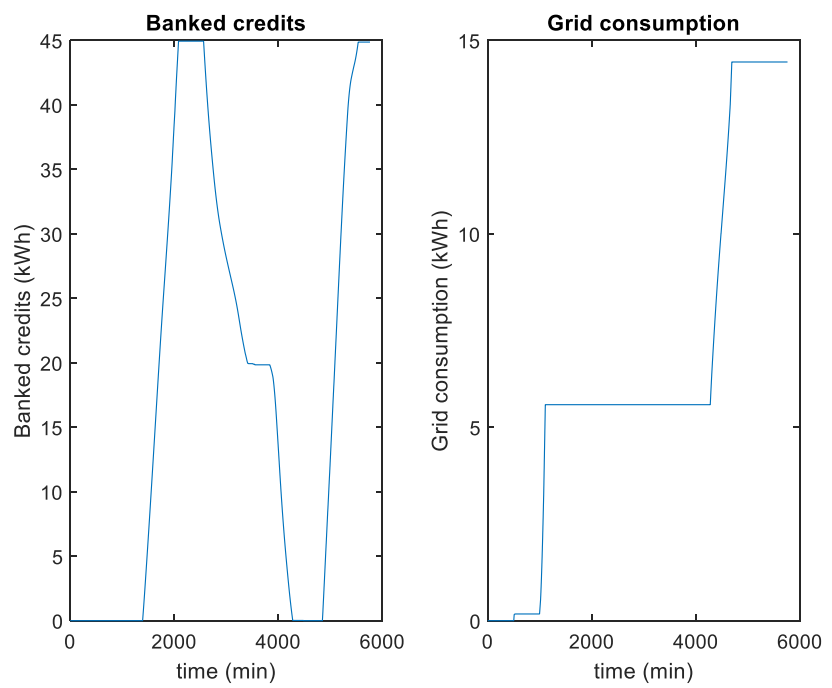

Fig. 5 Grid parameters for a four days simulation to $60 \%$ of its original cost during three consecutive years. The rapid decay in the predicted natural gas tariff was due to the decentralization program on the Brazilian NG market, initiated in 2018 [10].

For the economic assessment, first a net present value evaluation NPV of the system's operation is calculated according to Eq. (8).

$N P V=-I N V+\sum_{i=0}^{N} \frac{C F_{(i)}}{(1+r)^{i}}$

The NPV represents all cash flows (US\$) of a project (incoming and outgoing) evaluated at present $(t=0)$ [39]. In Eq. (8), INV correspond to the total investment on the project (US\$), representing a negative input cashflow at the beginning of system's operation. All equipment costs and each corresponding manufacturer are presented in Appendix Table 13. $C F_{(i)}$ is the cashflow (US\$) at year $i$, which can be a positive or negative value and $r$ is the interest rate (taken as $2.5 \%$ a year) [39]. NPV must be positive for the system to be viable. 
Secondly, the cumulative cost of each system configuration during ten years operation, for an installation of the system in the 2020 to 2040 horizon, is introduced as another parameter of economic analysis. In this to work, future aquisition costs of each power source in the system needed to be estimated for the next two decades. No reduction costs were considered in inverters acquisition. A linear decay function was used to interpolate IRENA's estimates on battery decaying prices up to 2040 [26], detailed in [29]. Eqs. (9) and (10) were used to estimate PV and CHP (PEMFC + NG reformer) decaying acquisition costs, according to data available in $([27,42]$, where $y$ corresponds to the year.

$$
\begin{aligned}
& F C(y)=F C(y=2020) \exp (0.3182(y-2020))^{-0.2367} \\
& P V(y)=P V(y=2020)\left[(1+0.09)^{(y-2020)}\right]^{-0.2875}
\end{aligned}
$$

Figures 6, 7 and 8 show the decaying costs projections for each equipment in the horizon considered.

As seen in Fig. 7, PV modules prices will continue to decrease continuously within the next twenty years, but with a slower pace compared to the last decades, achieving almost $40 \%$ reduction by 2040 . Following the projections, lead-acid batteries will experiment an even greater reduction on its purchase prices (approximately $65 \%$ in the same time interval). Finally, fuel cells are expected to have the major cost reductions as they are currently in the beginning of commercialization process, allowing for a $75 \%$ price decrease up to 2040. The resulting decay curve for the fuel cell / CHP investment was very similar to the predictions available in [41] study, thus serving as a partial validation of the economic model developed in this work.

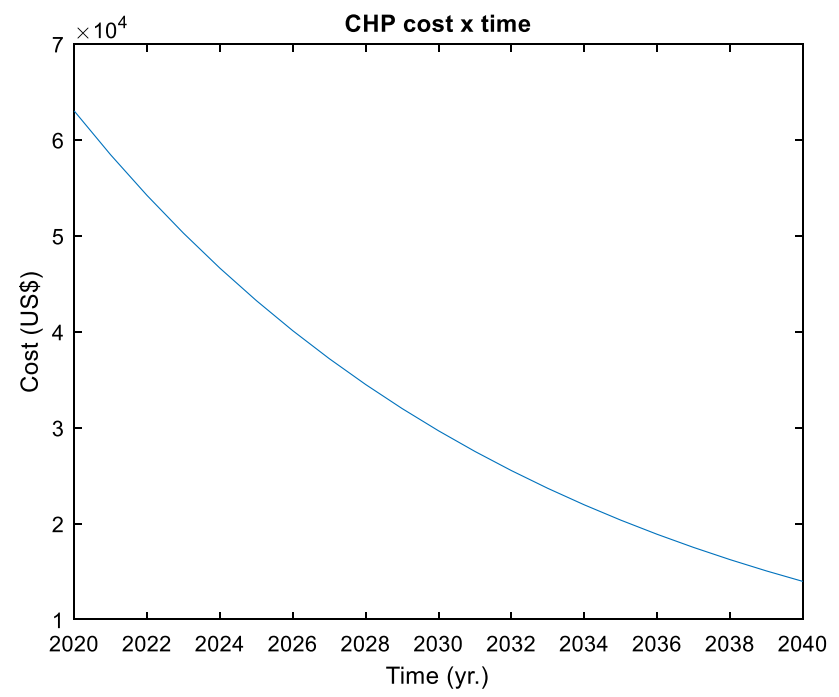

Fig. $65 \mathrm{~kW}$ Fuel cell + NG reformer acquisition cost projection in the 2020 to 2040 horizon

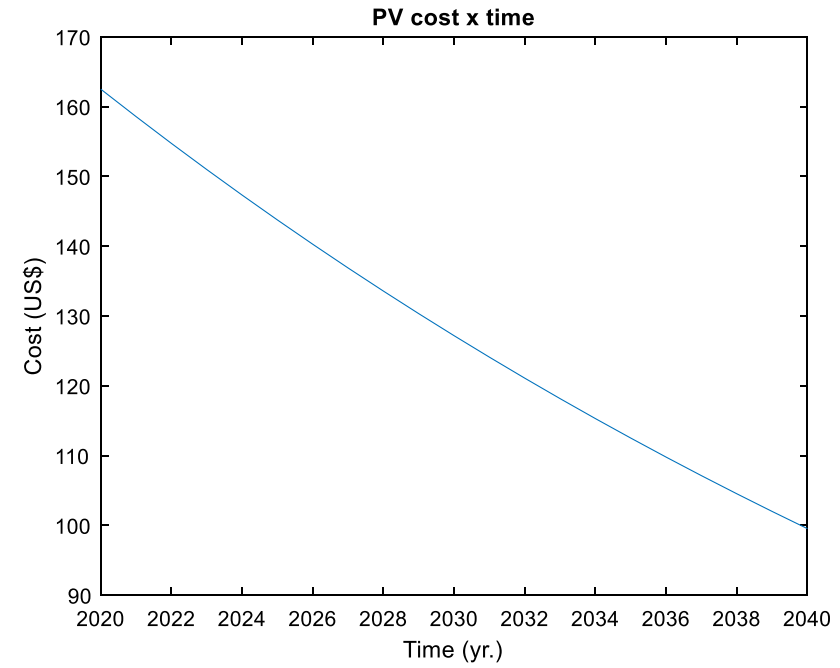

Fig. 7 245 W PV modules acquisition cost projection in the 2020 to 2040 horizon

\section{GHG Emission Impact Study}

The GHG emission study included in this work aimed to evaluate the total impact (in terms of $\mathrm{gCO}_{2} / \mathrm{kWh}$ ) for a few cases of interest of the proposed system. Total contributions were divided in system components production and manufacturing process and operational $\mathrm{CO}_{2}$ emissions from the power sources involved. In this study, all other greenhouse pollutants such as methane $\left(\mathrm{CH}_{4}\right)$ and nitrous oxide $\left(\mathrm{NO}_{x}\right)$ were accounted for their equivalent environmental impact in a $\mathrm{gCO}_{2} / \mathrm{kWh}$ basis. PV panels contribution to $\mathrm{CO}_{2}$ emission was considered to be fully of operational nature since major part of literature work on this area gather all modules

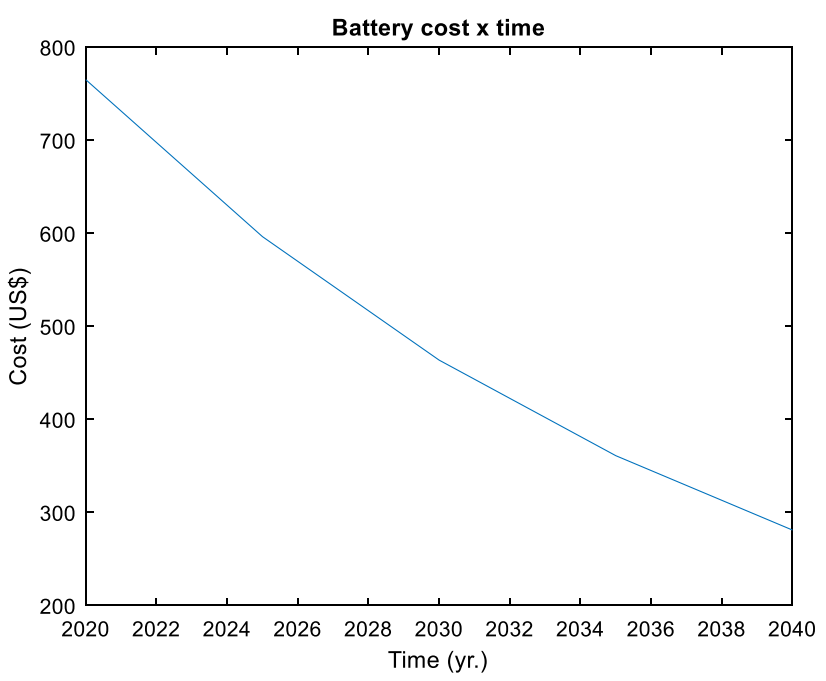

Fig. $8100 \mathrm{Ah} / 48 \mathrm{~V}$ battery acquisition cost projection in the 2020 to 2040 horizon 
Table 1 Total equivalent $\mathrm{CO}_{2}$ contribution from each system components production and manufacturing process

\begin{tabular}{llll}
\hline Components & $\begin{array}{l}\mathrm{CO}_{2} \text { emission } \\
(\mathrm{kgCO} / \mathrm{kWe})\end{array}$ & $\begin{array}{l}\mathrm{CO}_{2} \text { emission } \\
(\mathrm{kg} \mathrm{CO} / \mathrm{kWh})\end{array}$ & $\begin{array}{l}\mathrm{CO}_{2} \text { emission } \\
(\mathrm{kg} \mathrm{CO} / \mathrm{un} .)\end{array}$ \\
\hline $\mathrm{CHP}$ & 36.20 & - & 182.00 \\
Battery & - & 37.63 & 180.60 \\
Inverter & 26.30 & - & 178.84 \\
\hline
\end{tabular}

fabrication, operation and maintenance impact in a equivalent carbon dioxide per quilowatts-hour $\left(\mathrm{gCO}_{2} / \mathrm{kWh}\right)$ basis.

Table 1 shows all equipment production impact contribution considered in this work. For the $5 \mathrm{~kW}$ PEMFC / CHP, the average value available in Evangelisti [18] work was considered, while, for the inverters, estimations on bidirectional inverters for solar systems with energy storage was used [5]. On the other hand, a mean value from data found in the literature $[5,8]$ was considered for the $4.8 \mathrm{kWh}$ batteries.

Fuel cell operation, PV modules and conventional natural gas heaters (in cases when cogeneration with CHP was not accounted for) were the main contributors of the operational equivalent emission fraction. For PV modules, the mean value between [9], and [20] for polycristaline Si panels was used.

As natural gas composition was assumed as $100 \%$ methane in this work and as each $\mathrm{CH}_{4}$ molecule generates one $\mathrm{CO}_{2}$ molecule during natural gas reforming process, the mass flow of $\mathrm{CO}_{2}$ (in $\mathrm{g} / \mathrm{min}$ ) was obtained from Eq. (11). In Eq. 11, $\mathrm{MW}_{\mathrm{CO}_{2}}$ and $\mathrm{MW} W_{\mathrm{CH} 4}$ are the molecular weight of carbon dioxide and methane $(\mathrm{kg} / \mathrm{kmol}), n_{\mathrm{CO}_{2}}$ and $n_{\mathrm{CH}_{4}}$ are the molar flows of $\mathrm{CO}_{2}$ and $\mathrm{CH}_{4}(\mathrm{kmol} / \mathrm{min}), v_{\text {gas }}$ is the natural gas flow $\left(\mathrm{m}^{3} / \mathrm{min}\right)$ and $\rho_{\text {gas }}$ is the density of natural gas under standard conditions $\left(0.76 \mathrm{~kg} / \mathrm{m}^{3}\right)$.

$m_{\mathrm{CO}_{2}}=\mathrm{MW}_{\mathrm{CO}_{2}} n_{\mathrm{CO}_{2}}=M W_{\mathrm{CO}_{2}} n_{\mathrm{CH} 4}=M W_{\mathrm{CO}_{2}} \frac{v_{\text {gas }} \rho_{\text {gas }}}{M W_{\mathrm{CH} 4}}$

Total equivalent energy (in $\mathrm{kWh}$ ) associated with the natural gas entering the CHP $\left(E_{C H P}\right)$ was obtained from Eq. (12), where $L H V_{g a s}$ is the lower heating value of natural gas under standard conditions $(14.37 \mathrm{kWh} / \mathrm{kg})$ and $V_{\text {gas }}$ is the total natural gas consumed at the end of system's operation $\left(\mathrm{m}^{3}\right)$.

$E_{C H P}=V_{\text {gas }} \rho_{\text {gas }} L H V_{\text {gas }}$

The total electric and thermal energy generated by the CHP (in Wh) were calculed by simple integration with electric and thermal power output from the CHP operation, as given by Eq. (13).

$E_{i=e l, t h}=\int_{0}^{t} P_{i=e l, t h} d t$
Table 2 Total equivalent $\mathrm{CO}_{2}$ contribution from each system's power source

\begin{tabular}{ll}
\hline Power Source & $\begin{array}{l}\mathrm{CO}_{2} \text { emission } \\
(\mathrm{g} \mathrm{CO} / \mathrm{kWh})\end{array}$ \\
\hline CHP (wo/ cogeneration) & 404.47 \\
CHP (w/ cogeneration) & 207.09 \\
PV Panels & 45.00 \\
NG Heater & 518.00 \\
Electricity Grid & 88.00 \\
\hline
\end{tabular}

Finally, the equivalent GHG emissions (in $\mathrm{gCO}_{2} e q / \mathrm{kWh}$ ) of CHP's operation with and without cogeneration are given through Eqs. (14) and (15), respectively. The first portion of the right hand side corresponds to the emission generated by the gas reform process within the CHP, while the second portion of the right hand side corresponds to the equivalent emission produced during the natural gas extraction, production and refining process (CHP entry). The value 49.98 $\mathrm{gCO}_{2} e q / \mathrm{kWh}$ is assumed for the equivalent emission per unit of energy of the processed natural gas [21].

$E M_{e l}=\frac{m_{\mathrm{CO}_{2}}}{E_{e l}}+\frac{49.98 E_{C H P}}{E_{e l}}$

$E M_{C H P}=\frac{m_{\mathrm{CO}_{2}}}{E_{e l}+E_{t h}}+\frac{49.98 E_{C H P}}{E_{e l}+E_{t h}}$

Table 2 shows the contribution of $\mathrm{CO}_{2}$ emissions through the operation of each power source of the proposed hybrid system. In cases where cogeneration was not accounted for, a typical residential heater using natural gas was used to supply the user's thermal demand, whose equivalent emission of $\mathrm{CO}_{2}$ was considered similar to the equivalent emission obtained for natural gas burn in thermoelectric power plants in Brazil [34]. The value available in the National Energy Balance [17] was assumed for the average $\mathrm{CO}_{2}$ emissions index generated in the Brazilian electricity energy matrix in $2018\left(88 \mathrm{gCO}_{2} / \mathrm{kWh}\right)$.

\section{Results and Discussions}

\section{Validation for Conventional PV Systems}

In order to validate the NPV modelling of the developed Matlab program, the configuration of the system with pure $\mathrm{PV}$ was simulated using the electricity tariff prices for two different Brazilian states (Rio de Janeiro and Santa Catarina). These states have been chosen for the reason that they present the greater electricity prices disparity in Brazil (0.1678 US\$/kWh for Rio de Janeiro and 0.1185 US\$/kWh 
for Santa Catarina, without taxes), thus providing a wider range for the proposed validation. The payback for the given system configuration was estimated and compared to those from Greener's predictions on the distributed generation from solar PV market in Brazil [22]. Table 3 presents all economic data acquired for a twenty-year simulation of the PV only configuration for two residential consumers in the two states, where both the estimated payback time from the program and the payback predictions by Greener are given.

It can be seen that the paybacks for residential cases were slightly below those presented in the report, the difference being attributed mainly to the outdated data contained in the Greener study, as it was carried out in the fourth quarter of 2019 (higher PV modules costs). The paybacks of industrial cases were slightly above those presented in the report, because, due to the absence of data related to low voltage industrial consumers in the report, the results calculated by the simulator were compared to the data estimated for low voltage commercial consumers. In this way, the differences in the simultaneity and PR (performance ratio) expected for both types of consumers lead to a small disparity for the forecasts in this case. Finally, the estimated average paybacks were very close to the estimates made by Greener, with differences between $5 \%$ and $20 \%$ of the data obtained, proving the effectiveness of the control logic and the use of the cashflow analysis tool developed for the project.

\section{Simulation for Two Consumers Cases}

Figs. 9 (a) and 10 (a) show the cashflow in net present value (NPV) through a twenty-year operation starting in 2020 for two residential and industrial consumers, respectively. Results correspond to the use of conventional tariff. On the other hand, Figs. 9 (b) and 10 (b) estimate the total cumulative cost of a ten-year system operation in the 2020 to 2040 horizon. Tables 4, 5, 6, and 7 present detailed data collected from NPV analysis for each type of consumer.
Table 3 Economic parameters for a twenty-year system's operation on PV only configuration for two residential consumers in Rio de Janeiro and Santa Catarina states

\begin{tabular}{llllll}
\hline Parameters & \multicolumn{2}{l}{ Residential } & & \multicolumn{2}{l}{ Industrial } \\
\cline { 2 - 3 } & Rio de Janeiro & Santa Catarina & & Rio de Janeiro & Santa Catarina \\
\hline Total Investment (US\$) & 24,415 & 24,415 & & 28,315 & 28,315 \\
Electric Energy (US\$) & 6064 & 4108 & & 6064 & 4105 \\
Maintenance (US\$) & 7500 & 7500 & & 9500 & 9500 \\
Inverters substitutions (US\$) & 9690 & 9690 & & 9690 & 9690 \\
Total System Cost (US\$) & 47,669 & 45,713 & & 53,569 & 51,610 \\
Final profit in NPV (US\$) & 115,358 & 64,644 & & 152,897 & 88,152 \\
Payback - Simulated (yr.) & 3.3 & 5.0 & & 2.9 & 4.5 \\
Payback - Greener (yr.) & 3.8 & 6.1 & & 2.6 & 4.3 \\
\hline
\end{tabular}

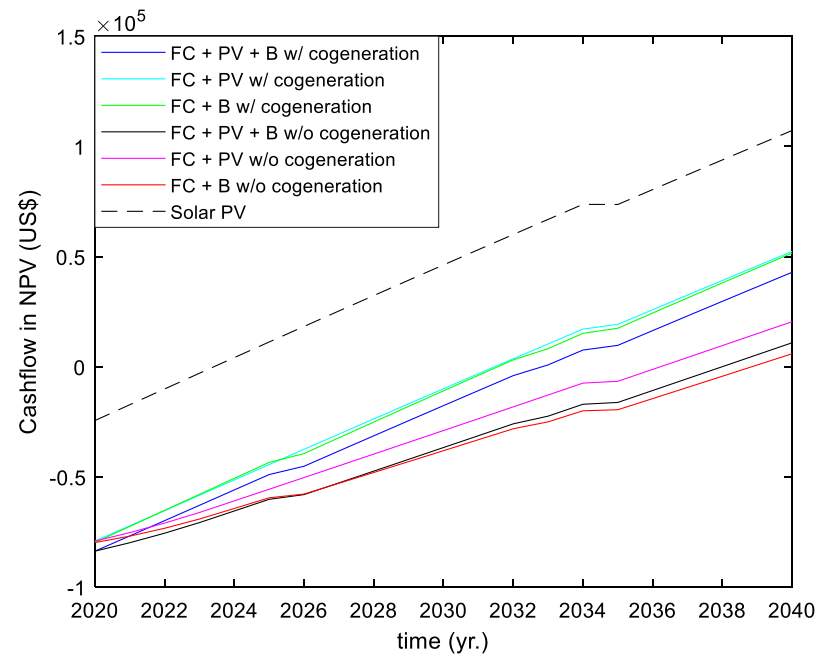

(a)

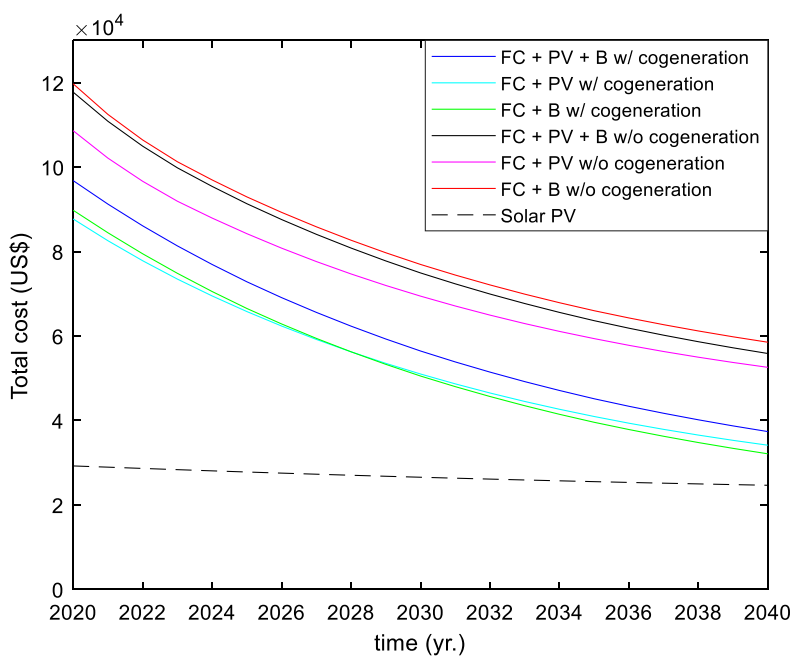

(b)

Fig. 9 a Cashflow in net present value (NPV) for twenty-year system's operation and (b) Total cost for ten-year system's operation in an 20202040 horizon for two residential consumers with conventional tariff 


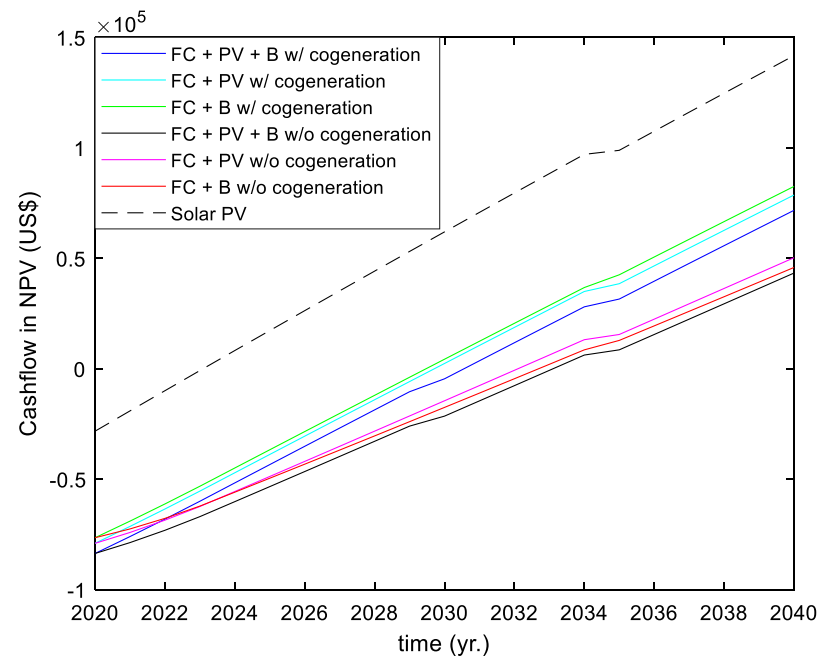

(a)

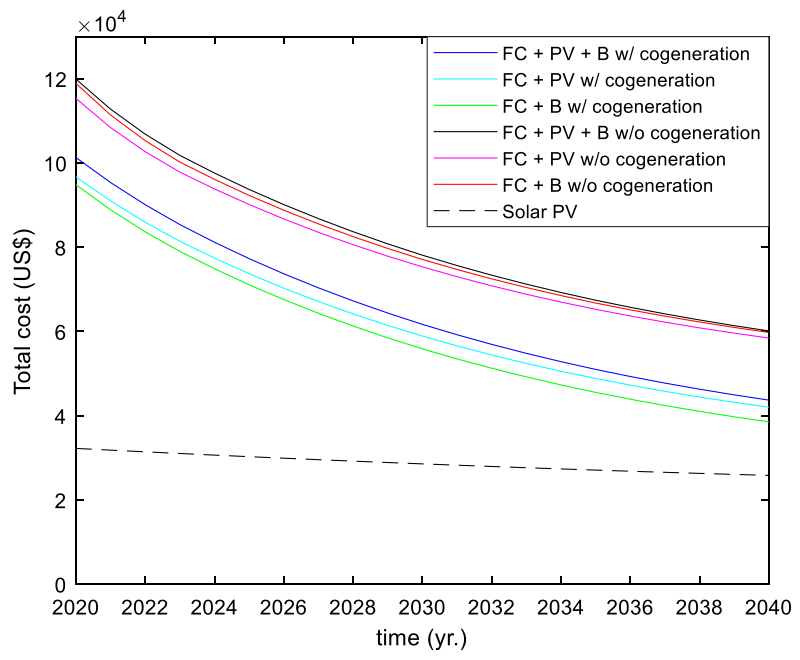

(b)

Fig. 10 a Cashflow in net present value (NPV) for twenty-year system's operation and (b) Total cost for ten-year system's operation in an 20202040 horizon for two industrial consumers with conventional tariff

Table 4 Technical data for 20-year system's operation for two residential consumers with conventional tariff

\begin{tabular}{|c|c|c|c|c|c|c|}
\hline \multirow[t]{2}{*}{ Parameters } & \multicolumn{3}{|c|}{ With Cogeneration } & \multicolumn{3}{|c|}{ Without Cogeneration } \\
\hline & $\mathrm{FC}+\mathrm{PV}+\mathrm{B}$ & $\mathrm{FC}+\mathrm{PV}$ & $\mathrm{FC}+\mathrm{B}$ & $\mathrm{FC}+\mathrm{PV}+\mathrm{B}$ & $\mathrm{FC}+\mathrm{PV}$ & $\mathrm{FC}+\mathrm{B}$ \\
\hline NG flow ( $\mathrm{m}^{3} /$ month) & 286.14 & 285.58 & 398.33 & 286.29 & 285.41 & 398.33 \\
\hline $\begin{array}{l}\text { Percentage of time } \\
\text { PEMFC operation } \\
(\%)\end{array}$ & 51.80 & 51.70 & 72.11 & 51.83 & 51.67 & 72.11 \\
\hline Bank substitutions & 2 & 0 & 2 & 2 & 0 & 2 \\
\hline Required inverters & 2 & 2 & 2 & 2 & 2 & 2 \\
\hline
\end{tabular}

Table 5 Economic data for 20-year system's operation for two residential consumers with conventional tariff

\begin{tabular}{|c|c|c|c|c|c|c|}
\hline \multirow[t]{2}{*}{ Parameters } & \multicolumn{3}{|c|}{ With Cogeneration } & \multicolumn{3}{|c|}{ Without Cogeneration } \\
\hline & $\mathrm{FC}+\mathrm{PV}+\mathrm{B}$ & $\mathrm{FC}+\mathrm{PV}$ & $\mathrm{FC}+\mathrm{B}$ & $\mathrm{FC}+\mathrm{PV}+\mathrm{B}$ & $\mathrm{FC}+\mathrm{PV}$ & $\mathrm{FC}+\mathrm{B}$ \\
\hline Total Investment (US\$) & 83,675 & 79,085 & 79,775 & 83,675 & 79,085 & 79,775 \\
\hline Electric Energy (US\$) & 7136 & 7339 & 7101 & 7138 & 7335 & 7101 \\
\hline Natural Gas (US\$) & 5134 & 5154 & 1190 & 44,602 & 44,500 & 57,566 \\
\hline Maint. \& Replc. (US\$) & 17,723 & 11,610 & 15,723 & 17,723 & 11,610 & 15,723 \\
\hline Total System Cost (US\$) & 113,668 & 103,188 & 103,789 & 153,138 & 142,530 & 160,165 \\
\hline Final Profit in NPV (US\$) & 42,892 & 52,354 & 51,615 & 10,903 & 20,467 & 5922 \\
\hline Payback (yr.) & 2033 & 2032 & 2032 & 2038 & 2037 & 2039 \\
\hline
\end{tabular}

All system configurations achieved payback before the year 2040 and required inverters substitution after fifteen years operation. Only two inverters and two battery bank substitutions were required in all residential cases. In cogeneration cases, a discount proportional to recovered heat from CHP and gas tariffs was made for each type of consumer, explaining the major gas bill cost reductions in these cases. Also, electric energy costs were very close to the minimum energy consumption of $100 \mathrm{kWh} /$ month stated for three-phase facilities connected to the grid, proving that the control system's algorithm worked well in deliverying power through system's components. Percentage time operation of fuel cell varied between $52 \%$ in residential PEMFC+PV systems to $92 \%$ in industrial PEMFC+B cases and final profits up to US\$ 82,000 were achieved, accounting for system's feasibility in all scenarios. Very little difference was observed in the final profit between $\mathrm{PEMFC}+\mathrm{PV}$ and $\mathrm{PEMFC}+\mathrm{B}$ configurations with the use of 
Table 6 Technical data for 20 -year system's operation for two industrial consumers with conventional tariff

\begin{tabular}{|c|c|c|c|c|c|c|}
\hline \multirow[t]{2}{*}{ Parameters } & \multicolumn{3}{|c|}{ With Cogeneration } & \multicolumn{3}{|c|}{ Without Cogeneration } \\
\hline & $\mathrm{FC}+\mathrm{PV}+\mathrm{B}$ & $\mathrm{FC}+\mathrm{PV}$ & $\mathrm{FC}+\mathrm{B}$ & $\mathrm{FC}+\mathrm{PV}+\mathrm{B}$ & $\mathrm{FC}+\mathrm{PV}$ & $\mathrm{FC}+\mathrm{B}$ \\
\hline NG flow (m³month) & 396.63 & 396.10 & 512.05 & 396.30 & 396.34 & 512.05 \\
\hline $\begin{array}{l}\text { Percentage of time } \\
\text { PEMFC operation } \\
(\%)\end{array}$ & 71.80 & 71.71 & 92.70 & 71.74 & 71.75 & 92.70 \\
\hline Bank substitutions & 1 & 0 & 0 & 1 & 0 & 0 \\
\hline Required inverters & 2 & 2 & 1 & 2 & 2 & 1 \\
\hline
\end{tabular}

\begin{tabular}{|c|c|c|c|c|c|c|}
\hline \multirow[t]{2}{*}{ Parameters } & \multicolumn{3}{|c|}{ With Cogeneration } & \multicolumn{3}{|c|}{ Without Cogeneration } \\
\hline & $\mathrm{FC}+\mathrm{PV}+\mathrm{B}$ & $\mathrm{FC}+\mathrm{PV}$ & $\mathrm{FC}+\mathrm{B}$ & $\mathrm{FC}+\mathrm{PV}+\mathrm{B}$ & $\mathrm{FC}+\mathrm{PV}$ & $\mathrm{FC}+\mathrm{B}$ \\
\hline Total Investment (US\$) & 83,675 & 79,085 & 76,545 & 83,675 & 79,085 & 76,545 \\
\hline Electric Energy (US\$) & 7127 & 7144 & 7103 & 7140 & 7133 & 7103 \\
\hline Natural Gas (US\$) & 22,308 & 22,294 & 25,461 & 57,331 & 57,336 & 70,725 \\
\hline Maint. \& Replc. (US\$) & 14,551 & 11,610 & 6380 & 14,551 & 11,610 & 6380 \\
\hline Total System Cost (US\$) & 127,661 & 120,133 & 115,489 & 162,697 & 155,164 & 160,753 \\
\hline Final Profit in NPV (US\$) & 71,658 & 78,602 & 82,491 & 43,262 & 50,209 & 45,805 \\
\hline Payback (yr.) & 2031 & 2030 & 2030 & 2034 & 2033 & 2033 \\
\hline
\end{tabular}

Table 7 Economic data for 20-year system's operation for two industrial consumers with conventional tariff cogeneration, where the later presented slighty reduced costs in the industrial case. On the other hand, without cogeneration, PEMFC+PV configuration tended to show better cost effectiveness (especially on residential case) because of lower NG consumption. It should be noted, however, that the battery bank provides an effective means of energy storage, which could temporarily provide all electricity demand in the system in case of CHP's malfunctioning or if connection to the grid was lost at any moment. Therefore, $\mathrm{FC}+\mathrm{B}$ or $\mathrm{FC}+\mathrm{PV}+\mathrm{B}$ configurations could be the ideal solution in case of critical applications, where security in energy supply is more important than the cost itself.

As evidenced by Figs. 9 (a) and 10 (a), the conventional PV systems were able to present a much larger profit at the end of 20 years operation because of extremely low initial investment. These results, however, couldchange considerably, according to Figs. 9 (b) and 10 (b). As fuel cells are currently in the beginning of comercialization process, major acquisition cost reductions expected for this technology within the next years may reshape system's cashflow and cumulative cost curves totally different. Even though some cost reduction is also expected for PV modules as well, other components / technologies of conventional PV systems are already fully mature in the market (for example the power inverters), explaining more flattened cost decay curves for such systems between 2020 and 2040.

\section{Simulation for Five Consumers Cases}

To investigate the impact of different electric energy tariffs and fuel cell sizing, a complete system $(\mathrm{FC}+\mathrm{PV}+\mathrm{B})$ was simulated under the same circunstances as before under conventional and alternative tariffs for five residential and industrial consumers. In these cases, however, only cogeneration scenarios were evaluated as to obtain the maximum profit as possible for the consumers. Again, a total of ten PV modules (245 W each) and three 100 Ah batteries were used per consumer.

Fig. 11 and Tables 8 and 9 show all data acquired along with the simulation for pure PV systems for the same power demand.

Both residential and industrial consumers required three inverters while running on conventional tariff and five inverters while on alternative tariff. Also, just one battery substitution was needed for industrial cases and three substitutions for residentional cases with conventional tariff, while five substitutions were required for both of them on alternative tariffs's cases. Even though the fuel cell opperated $100 \%$ of the time for all five consumers's cases $\left(552 \mathrm{~m}^{3} /\right.$ month of NG), complementary electric energy from the grid was needed to supply total demand, except for the residential case with alternative tariff. In fact, the alternative tariff strategy has a positive effect, allowing major energy cost reductions by forcing the batteries to shift power generation within the system to around $6 \mathrm{pm}$ and $9 \mathrm{pm}$. Thus, the system exports large amounts of energy to the grid when tariff is more expensive, generating more energy credits for use in other times of the day. That strategy comes with a price though, requiring the batteries to complete much more cycles than in the conventional tariff case, meaning more frequent bank substitutions and necessity for more inverters 


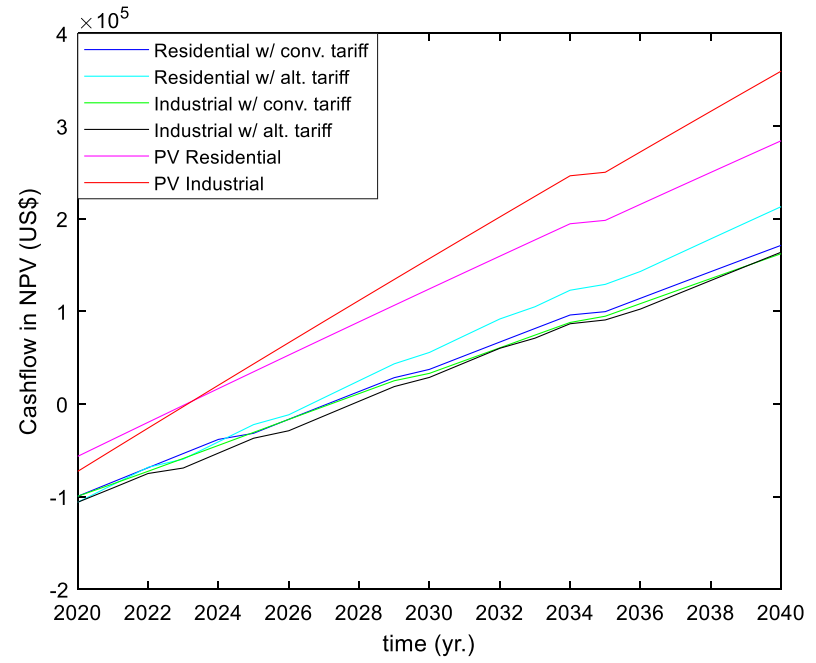

(a)

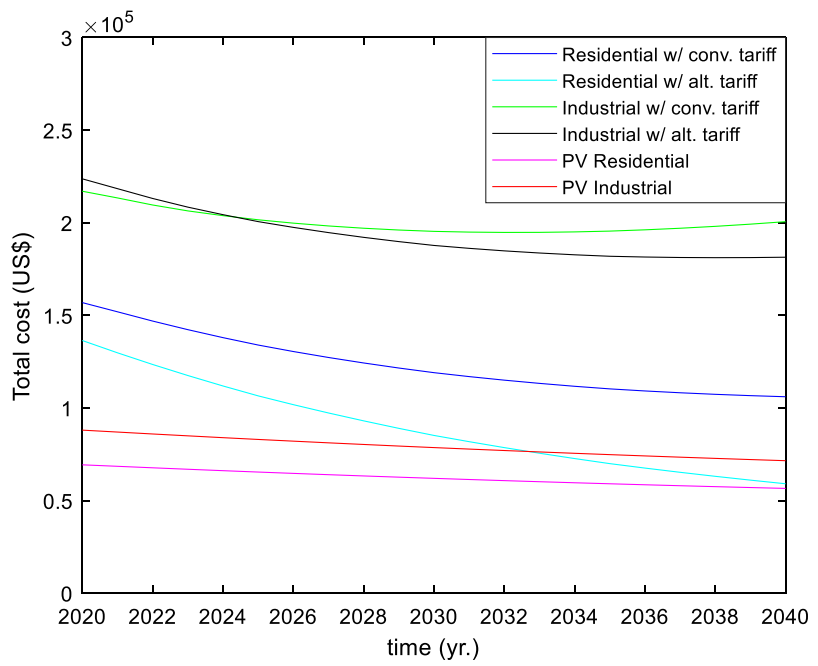

(b)

Fig. 11 (a) Cashflow in net present value (NPV) for twenty-year system's operation and (b) Total cost for ten-year system's operation in an 2020-2040 horizon for five consumers with conventional and alternative tariffs

Table 8 Technical data for 20-year system's operation for five consumers with both tariffs

\begin{tabular}{|c|c|c|c|c|c|c|}
\hline \multirow[t]{2}{*}{ Parameters } & \multicolumn{3}{|c|}{ Residential } & \multicolumn{3}{|c|}{ Industrial } \\
\hline & Conv. & Alt. & PV only & Conv. & Alt. & PV only \\
\hline NG flow ( $\mathrm{m}^{3} /$ month) & 552.34 & 552.36 & 0 & 552.38 & 552.38 & 0 \\
\hline $\begin{array}{l}\text { Percentage of time } \\
\text { PEMFC operation (\%) }\end{array}$ & 99.99 & 99.99 & 0 & 100 & 100 & 0 \\
\hline Bank substitutions & 3 & 5 & 0 & 1 & 5 & 0 \\
\hline Required inverters & 3 & 5 & 6 & 3 & 5 & 8 \\
\hline
\end{tabular}

Table 9 Economic data for 20-year system's operation for five consumers with both tariffs

\begin{tabular}{llllllll}
\hline Parameters & \multicolumn{2}{l}{ Residential } & & & & Industrial \\
& Conv. & Alt. & PV only & & Conv. & Alt. & PV only \\
\hline Total Investment (US\$) & 99,640 & 106,100 & 56,530 & & 99,640 & 106,100 & 72,740 \\
Electric Energy (US\$) & 92,080 & 7505 & 7109 & & 219,324 & 169,748 & 7113 \\
Natural Gas (US\$) & 0 & 0 & 0 & & 26,636 & 26,636 & 0 \\
Maint. \& Replc. (US\$) & 40,366 & 62,813 & 38,380 & & 25,193 & 62,813 & 49,840 \\
Total System Cost (US\$) & 232,086 & 176,418 & 102,019 & & 370,793 & 365,297 & 129,693 \\
Final Profit in NPV (US\$) & 171,289 & 213,036 & 284,166 & & 162,253 & 163,877 & 359,351 \\
Payback (yr.) & 2028 & 2027 & 2024 & & 2028 & 2028 & 2024 \\
\hline
\end{tabular}

to perform great power flow during peak hours. Because the most part of consumer demand is concentrated during peak hours for the residential case, the alternative tariff strategy provided higher reduction on energy cost than the industrial case, allowing total profit of US\$213,000 at the end of system's operation.

Again, it can be seen that, in the year 2020, conventional PV systems (without batteries) are still much cheaper to generate the same amount of energy than que proposed system, achieving paybacks before four years operation time. On the other hand, as shown in Fig. 11 (b), major cost reductions in total system operation costs can be obtained when considered beginning of system's operation several years ahead, mainly due to cheaper investment on system components (specially the PEMFC unit). For the residential case, the $\mathrm{FC}+\mathrm{PV}+\mathrm{B}$ system would become economically competitive with PV only systems by the year 2040, when alternative tariff strategy is considered. 
Simulation with alternative tariff for two consumers's cases were performed but no advantage was observed due to low energy consumption from the grid. In other words, the alternative tariff strategy could not reduce energy bill costs while the system was oversized, thus presenting worse results than the conventional tariff due to more battery bank substituitions and additional inverters required.
$\mathrm{CO}_{2}$ Equivalent Emissions for Two Consumers Cases

Tables 10 and 11 present the GHG impact study for two residential and industrial consumers in terms of $\mathrm{gCO}_{2} e q / \mathrm{kWh}$ considered in this work. Total consumers' power and thermal demands and electric power generated / consumed by each power source in the system are shown. Also, each power source percentage contribution to the supply of total demand and equivalent $\mathrm{CO}_{2}$ emissions of component's manufacturing
Table $10 \mathrm{CO}_{2}$ equivalent emissions for two residential consumers with conventional tariff
Table $11 \mathrm{CO}_{2}$ equivalent emissions for two industrial consumers with conventional tariff

\begin{tabular}{|c|c|c|c|c|c|c|}
\hline \multirow[t]{2}{*}{ Parameters } & \multicolumn{3}{|c|}{ With Cogeneration } & \multicolumn{3}{|c|}{ Without Cogeneration } \\
\hline & $\mathrm{FC}+\mathrm{PV}+\mathrm{B}$ & $\mathrm{FC}+\mathrm{PV}$ & $\mathrm{FC}+\mathrm{B}$ & $\mathrm{FC}+\mathrm{PV}+\mathrm{B}$ & $\mathrm{FC}+\mathrm{PV}$ & $\mathrm{FC}+\mathrm{B}$ \\
\hline Electric demand (kWh) & 645,269 & 645,269 & 645,269 & 645,269 & 645,269 & 645,269 \\
\hline $\mathrm{PV}$ generation $(\mathrm{kWh})$ & 175,042 & 175,430 & 0 & 175,037 & 174,751 & 0 \\
\hline CHP elec. Generation (kWh) & 447,422 & 445,959 & 623,028 & 447,554 & 446,654 & 623,028 \\
\hline Grid consumption (kWh) & 22,805 & 23,879 & 22,241 & 22,677 & 23,863 & 22,241 \\
\hline Thermal demand (kWh) & 426,449 & 425,055 & 593,823 & 426,575 & 425,717 & 593,823 \\
\hline \multicolumn{7}{|c|}{ Operational Contributions (energy supply per source) } \\
\hline $\mathrm{CHP}(\%)$ & 81.54 & 81.38 & 98.21 & 41.76 & 41.70 & 50.28 \\
\hline $\mathrm{PV}(\%)$ & 16.33 & 16.39 & 0.00 & 16.33 & 16.32 & 0.00 \\
\hline Grid $(\%)$ & 2.13 & 2.23 & 1.79 & 2.12 & 2.23 & 1.79 \\
\hline NG burner $(\%)$ & 0.00 & 0.00 & 0.00 & 39.80 & 39.75 & 47.92 \\
\hline eq. emissions ( $\mathrm{g} \mathrm{CO} / \mathrm{kWh}$ ) & 178.08 & 177.87 & 204.95 & 384.25 & 383.89 & 453.20 \\
\hline \multicolumn{7}{|c|}{ Components' Manufacturing \& Replacement Contribution } \\
\hline $\mathrm{CHP}\left(\mathrm{g} \boldsymbol{C} \boldsymbol{O}_{2} / \mathrm{kWh}\right)$ & 0.17 & 0.17 & 0.15 & 0.17 & 0.17 & 0.15 \\
\hline Batteries ( $\left.\mathrm{g} \boldsymbol{C} \boldsymbol{O}_{2} / \mathrm{kWh}\right)$ & 3.03 & 0.00 & 2.62 & 3.03 & 0.00 & 2.62 \\
\hline Inverters $\left(\mathrm{g} \boldsymbol{C} \boldsymbol{O}_{2} / \mathrm{kWh}\right)$ & 0.67 & 0.67 & 0.58 & 0.67 & 0.67 & 0.58 \\
\hline \multicolumn{7}{|l|}{ TOTAL } \\
\hline Total (g $\left.\mathrm{CO}_{2} / \mathrm{kWh}\right)$ & 181.95 & 178.70 & 208.30 & 388.12 & 384.73 & 456.55 \\
\hline
\end{tabular}

\begin{tabular}{|c|c|c|c|c|c|c|}
\hline \multirow[t]{2}{*}{ Parameters } & \multicolumn{3}{|c|}{ With Cogeneration } & \multicolumn{3}{|c|}{ Without Cogeneration } \\
\hline & $\mathrm{FC}+\mathrm{PV}+\mathrm{B}$ & $\mathrm{FC}+\mathrm{PV}$ & $\mathrm{FC}+\mathrm{B}$ & $\mathrm{FC}+\mathrm{PV}+\mathrm{B}$ & $\mathrm{FC}+\mathrm{PV}$ & $\mathrm{FC}+\mathrm{B}$ \\
\hline Electric demand (kWh) & 817,198 & 817,198 & 817,198 & 817,198 & 817,198 & 817,198 \\
\hline PV generation $(\mathrm{kWh})$ & 174,753 & 174,812 & 0 & 175,108 & 174,747 & 0 \\
\hline CHP elec. Generation (kWh) & 620,226 & 619,820 & 800,889 & 619,694 & 619,867 & 800,889 \\
\hline Grid consumption $(\mathrm{kWh})$ & 22,219 & 22,566 & 16,310 & 22,396 & 22,584 & 16,310 \\
\hline Thermal demand (kWh) & 591,153 & 590,766 & 763,347 & 590,646 & 590,811 & 763,347 \\
\hline \multicolumn{7}{|c|}{ Operational Contributions (energy supply p. source) } \\
\hline $\mathrm{CHP}(\%)$ & 86.01 & 85.98 & 98.97 & 44.02 & 44.02 & 50.67 \\
\hline PV $(\%)$ & 12.41 & 12.42 & 0.00 & 12.44 & 12.41 & 0.00 \\
\hline Grid $(\%)$ & 1.58 & 1.60 & 1.03 & 1.59 & 1.60 & 1.03 \\
\hline NG burner $(\%)$ & 0.00 & 0.00 & 0.00 & 41.95 & 41.96 & 48.30 \\
\hline eq. emissions ( $\mathrm{g} \mathrm{CO} / \mathrm{kWh})$ & 185.10 & 185.06 & 205.86 & 402.35 & 402.42 & 456.04 \\
\hline \multicolumn{7}{|c|}{ Components' Manufacturing \& Replacement Contribution } \\
\hline $\mathrm{CHP}\left(\mathrm{g} \boldsymbol{C} \boldsymbol{O}_{2} / \mathrm{kWh}\right)$ & 0.13 & 0.13 & 0.12 & 0.13 & 0.13 & 0.12 \\
\hline Batteries (g $\left.\boldsymbol{C} \boldsymbol{O}_{2} / \mathrm{kWh}\right)$ & 1.54 & 0.00 & 0.69 & 1.54 & 0.00 & 0.69 \\
\hline Inverters $\left(\mathrm{g} \boldsymbol{C} \boldsymbol{O}_{2} / \mathrm{kWh}\right)$ & 0.51 & 0.51 & 0.23 & 0.51 & 0.51 & 0.23 \\
\hline \multicolumn{7}{|l|}{ TOTAL } \\
\hline Total $(\mathrm{g} \mathrm{CO} / \mathrm{kWh})$ & 187.27 & 185.69 & 206.89 & 404.53 & 403.06 & 457.06 \\
\hline
\end{tabular}


process (including battery bank and inverters replacement) are also informed. No variation in GHG emissions was observed between the conventional and alternative strategies for the electricity impact study and, thus, the results for five consumers cases were not shown in the current analysis.

It can be observed, from the obtained results, that the use of cogeneration with the CHP heat rejection has a great impact over total $\mathrm{CO}_{2}$ produced by unit of energy. This highlights the benefits of cogeneration in both economic and environmental performance for the proposed hybrid system, where total $\mathrm{CO}_{2}$ emissions could be reduced from aproximately 388 to 182 $\mathrm{gCO}_{2} e q / k W h$ for the complete system $(\mathrm{FC}+\mathrm{PV}+\mathrm{B})$ for the residential case. Additionally, the inclusion of the $\mathrm{PV}$ modules seemed to significantly improve the system's performance in an environmental point of view. As a meaningful part of the electric demand is provided by the solar power source, the fuel cell needs to operate less time in the $\mathrm{FC}+\mathrm{PV}+\mathrm{B}$ and $\mathrm{FC}+\mathrm{PV}$ cases, reducing the total $\mathrm{gCO}_{2} e q / \mathrm{kWh}$ generated. Also, it can be seen that the total contribution of each equiment production / manufacturing process has minor effects over total operational contributions of the power sources (PV and CHP), mainly due to the high energy generated during the 20 year's operation, which dilutes the components manufacturing process GHG impact.

Finally, if all the electric and thermal demands were provided solely by the Brazilian electricity grid and natural gas heater, the total $\mathrm{CO}_{2}$ emission would be 259.14 $\mathrm{gCO}_{2} e q / \mathrm{kWh}$ and $268.39 \mathrm{gCO}_{2} e q / \mathrm{kWh}$, respectively for the residential and industrial cases. Furthermore, even though conventional PV systems usually present equivalent emissions of $40 \mathrm{gCO}_{2} e q / \mathrm{kWh}$ to $80 \mathrm{gCO}_{2} e q / \mathrm{kWh}[9,20]$, if a natural gas heater is also used to supply the corresponding thermal demand for the residential consumer, total emission could rise up to $233.25 \mathrm{gCO}_{2} e q / \mathrm{kWh}$ for such systems. Therefore, the proposed on-grid hybrid system proved to be an interesting alternative solution to other green energy systems by presenting relatively low pollutant emission to the environment when cogeneration is considered.

\section{Conclusions and Perspectives}

An hybrid system was presented and simulated under different system configurations and two type of tariffs, allowing for cogeneration from high temperature operation of the CHP unit. Energy and economic assessments were made and proved for the system's viability in all discussed scenarios, where great economic advantages were achieved as compared to direct electric energy consumption from the grid. Paybacks between 7 and 19 years of system's operation were achieved for different combinations of the studied parameters considering beginning of operation in 2020. Additionally, more than $50 \%$ reductions in total system cumulative cost were obtained considering the predicted decrease in system's components acquisition costs for the next two decades. For two consumers cases, the best scenario was achieved with the $\mathrm{FC}+\mathrm{PV}$ configuration for the residential load profile and the $\mathrm{FC}+\mathrm{B}$ configuration for the industrial load profile, mainly due to different power demand fluctuation throughout the day. Additionally, for five consumers cases, it was found that the alternative tariff strategy could provide significantly cost reductions only when system was undersized because of relatively high battery bank substitutions costs. From the GHG impact study, it could be seen that the proposed system presented relatively low $\mathrm{CO}_{2}$ emissions when cogeneration with CHP heat rejection was included in the analysis. The best scenario was obtained with the $\mathrm{FC}+\mathrm{PV}$ configuration, where operational emissions were approximately equal to the $\mathrm{FC}+\mathrm{PV}+\mathrm{B}$ configuration, but components production and manufturing had a minor contribution due to the absence of the battery bank. Considering cogeneration, total calculated emissions were $178.7 \mathrm{gCO}_{2} e q / \mathrm{kWh}$ (residential case) and $185.69 \mathrm{gCO}_{2} e q / \mathrm{kWh}$ (industrial case) for this configuration. Thus, the proposed system could reduce total emissions up to $31 \%$ when compared to the complete power and thermal supply by the Brazilian Electricity grid and natural gas heater (estimated as 259.14 $\mathrm{gCO}_{2} e q / \mathrm{kWh}$ and $268.39 \mathrm{gCO}_{2} e q / \mathrm{kWh}$, respectively, for the consumers). The results show that, beyond requiring much less space for equipment installation, the analysed system has the advantage of power shifting control throughout the day over conventional PV systems. As consequence, less dependence on reverse metering factor variation is expected from the former. Finally, the battery bank could sustain energy supply even if connection to the grid was lost at any moment, providing an efficient back-up for consumer's power demand, opening up several potential applications for the proposed system.

In future works, an experimental validation of the developed simulation tool is considered of great interest for this work. Additionally, several modules can be added to the proposed simulation tools. For instance, a control algorithm with the use of neural networks or fuzzy-logic based techniques should be elaborated in order to maximise system's performance in both efficiency and economic viewpoints. Also, a more realistic value for hydrogen stoichiometry in FC reactions and different NG compositions should also be examined as to obtain a more accurate result for system's efficiency and to extend the system's applicability on different regions of the planet. A sensitivity analysis for various fuel purchasing and power selling price would lead to more realistic pay back times. Moreover, an exergy analysis should be caried out in order to identify possible improvements on system arrangement and process. Also, PEMFC stack substitutions should be considered after stack lifespan is reached. A model of battery degradation can also be added. Finally, a comparison with other types of load profiles (as commercial consumers) for small and medium power applications should also be evaluated. 


\section{Appendix}

Fig. 12 Control algorithm for power flow through the system for each PEMFC operation condition (turned off, warming up, power production and cooling down). a) Turned off, b) Warming up, c) Power production, d) Cooling down a) Turned off

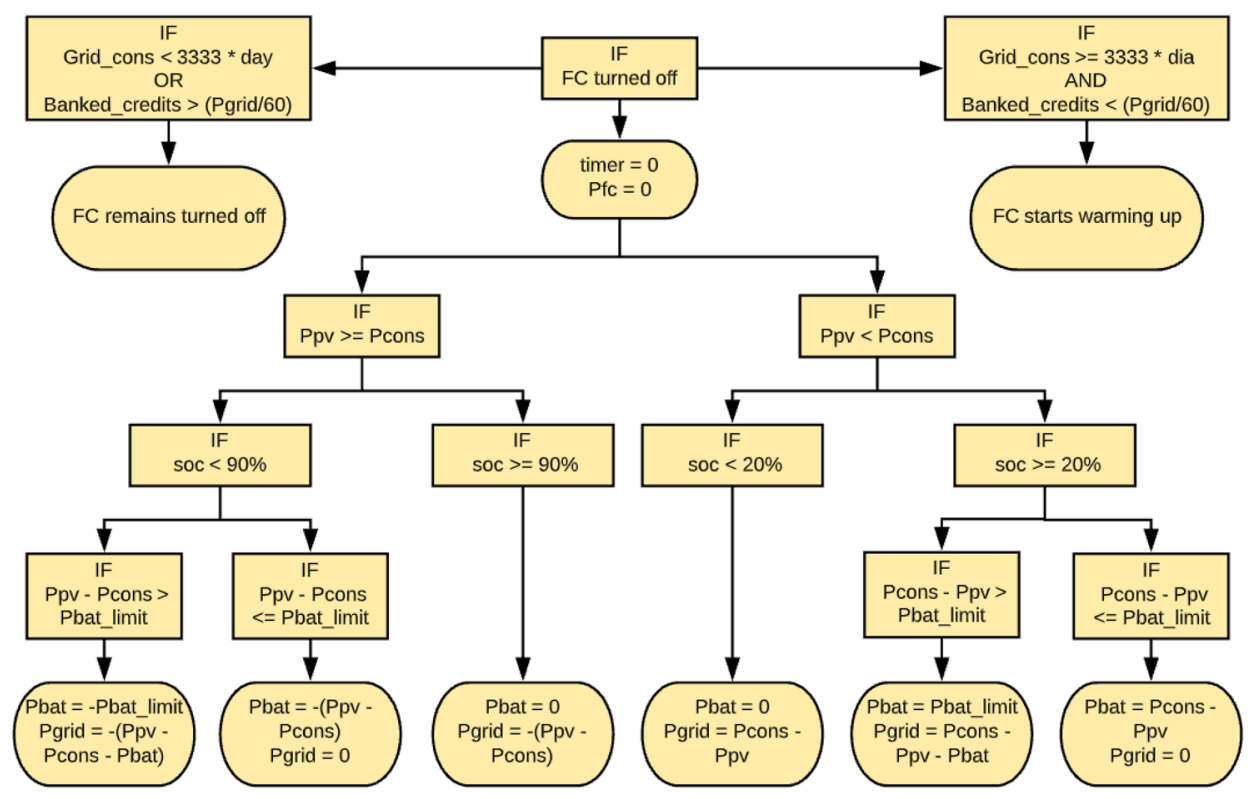

b) Warming up

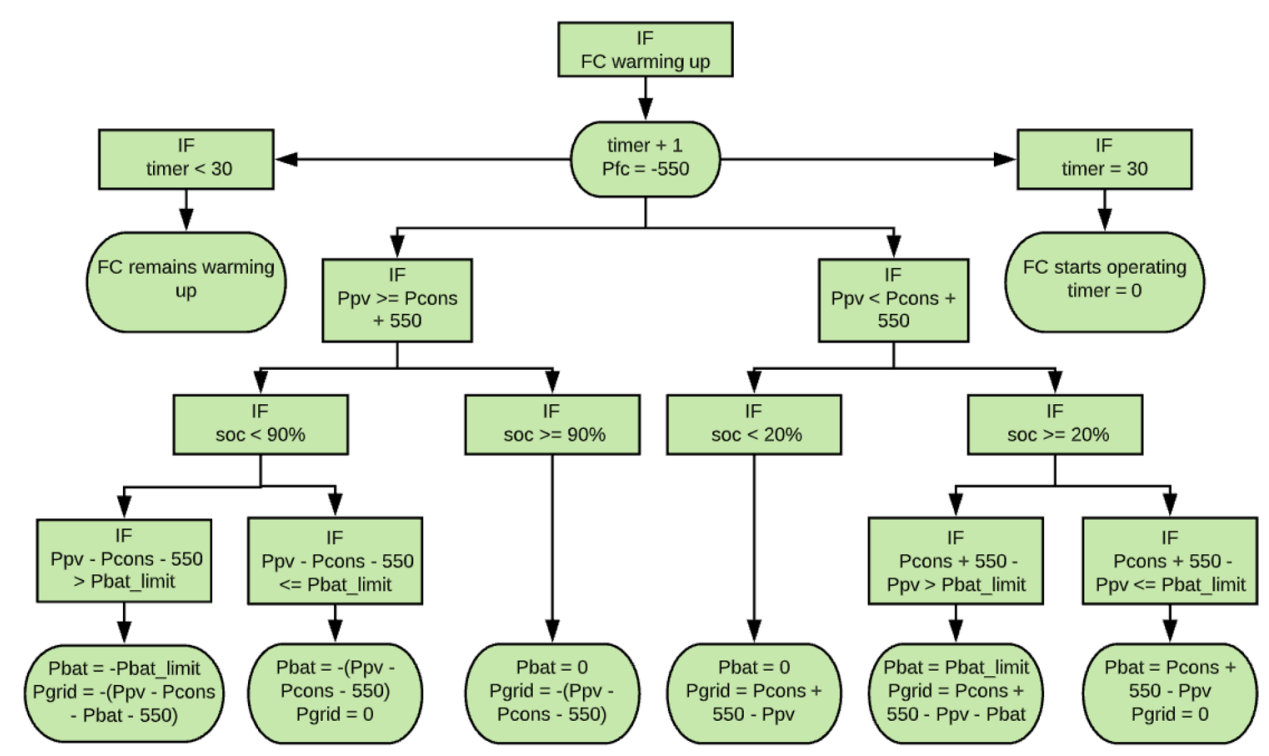


Fig. 12 (continued)

c) Power production

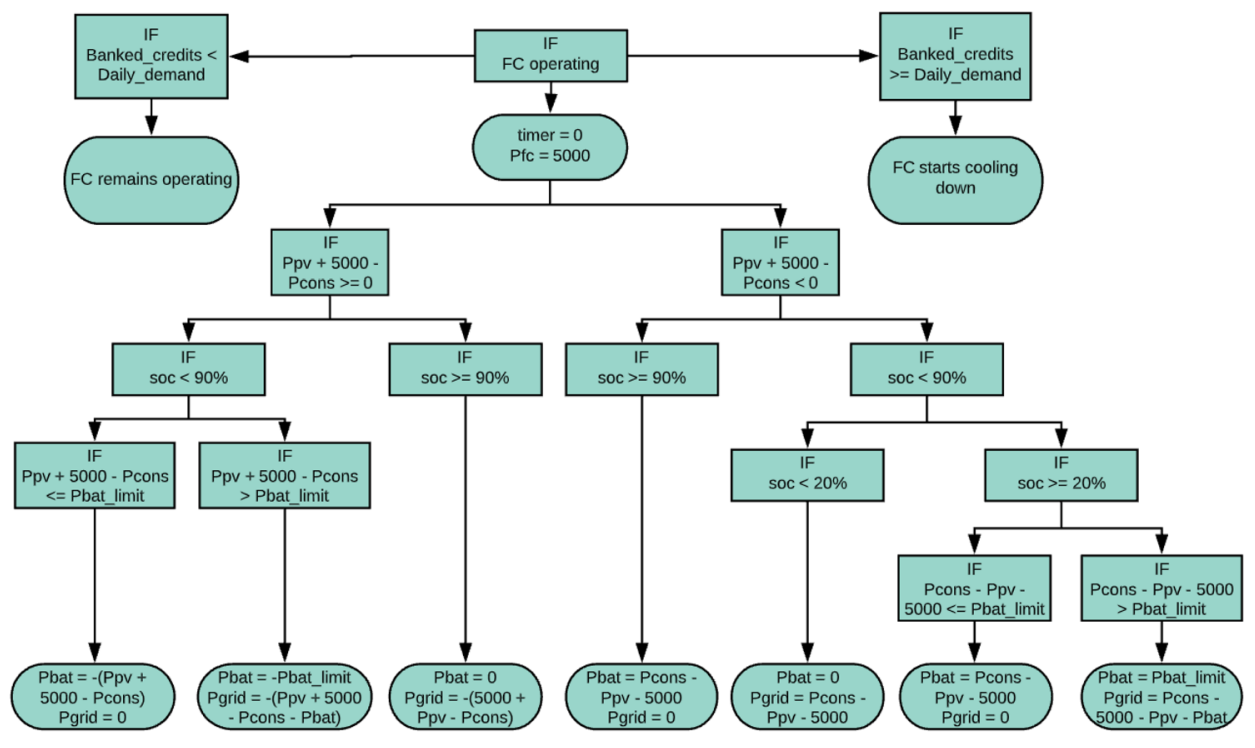

d) Cooling down

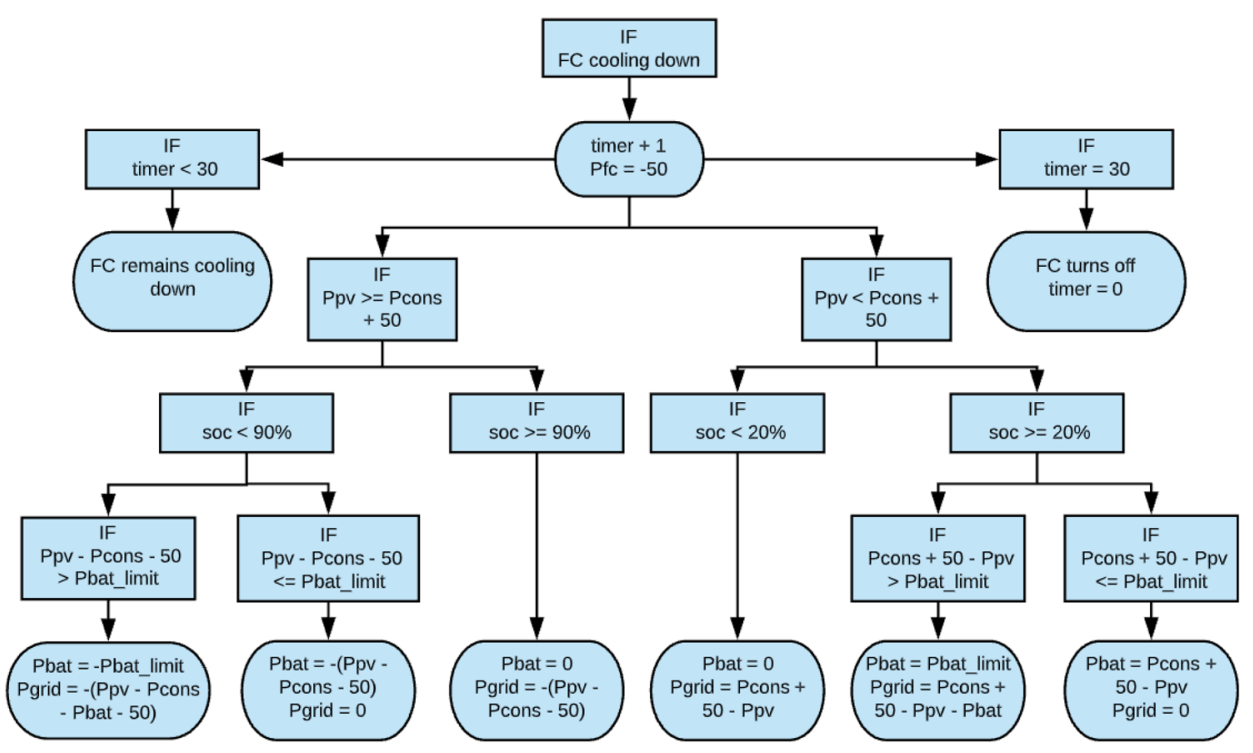


Table 12 Grid electricity and natural gas costs used in this study

\begin{tabular}{|c|c|c|c|c|}
\hline \multicolumn{2}{|l|}{ Electric energy } & \multicolumn{3}{|l|}{ Natural gas } \\
\hline Type of tariff & Cost (US\$/kWh) & Type of consumer & $\begin{array}{l}\text { Consume range } \\
\left(\mathrm{m}^{3} / \mathrm{month}\right)\end{array}$ & $\begin{array}{l}\text { Cost } \\
\left(\mathrm{US} \$ / \mathrm{m}^{3}\right)\end{array}$ \\
\hline Conventional & 0.244 & \multirow{2}{*}{$\begin{array}{l}\text { Distributed } \\
\text { Generation }\end{array}$} & $0-200$ & 1.127 \\
\hline \multirow[t]{3}{*}{ Alternative (low) before 17:00 and after 22:00 } & \multirow[t]{3}{*}{0.215} & & $201-5000$ & 0.753 \\
\hline & & \multirow[t]{2}{*}{ Residential } & $0-7$ & 1.543 \\
\hline & & & $8-23$ & 2.012 \\
\hline \multirow[t]{3}{*}{ Alternative (inter.) $17: 00$ to $18: 00$ and $21: 00$ to $22: 00$} & \multirow[t]{3}{*}{0.297} & & $24-83$ & 2.437 \\
\hline & & & above 84 & 2.572 \\
\hline & & Industrial & $0-200$ & 1.507 \\
\hline \multirow[t]{2}{*}{ Alternative (high) 18:00 to $21: 00$} & \multirow[t]{2}{*}{0.445} & & $201-500$ & 1.463 \\
\hline & & & above 500 & 1.420 \\
\hline
\end{tabular}

Table 13 Equipment costs considered in this study

\begin{tabular}{lllll}
\hline Equipment & $\begin{array}{l}\text { Acquisition Cost } \\
\text { (US\$/unit) }\end{array}$ & $\begin{array}{l}\text { Instalation Cost } \\
\text { (US\$/unit) }\end{array}$ & $\begin{array}{l}\text { Mainte- } \\
\text { nance Cost } \\
\text { (US\$/unit/ } \\
\text { year) }\end{array}$ & Manufacturer \\
\hline Micro CHP w/ 5 kW PEMFC Unit & 63,000 & 5625 & 157.5 & Helbio \\
6.8 kW Bidirectional Inverter & 3230 & & - & Intermepro \\
48 V / 100 Ah VRLA Battery & 765 & - & - & Moura \\
245 W PV pannel & 162 & 32.5 & 5.0 & Yingli \\
\hline
\end{tabular}

Acknowledgements This study was financed in part by the Coordenação de Aperfeiçoamento de Pessoal de Nível Superior-Brasil (CAPES)_Finance Code 001. The authors would like to thank the $\mathrm{CNPq} / \mathrm{MCTIC}$ and FAPERJ for the financial support to the Department of Mechanical Engineering (DEM) at the Pontifical Catholic University of Rio de Janeiro (PUC-Rio). The authors gratefully acknowledge Guascor do Brasil for the financial support, through its ANEEL R\&D budget.

\section{Declarations}

Conflict of Interests The authors declare that there is no conflict of interests.

\section{References}

1. Abdulkareem AS, Afolabi AS, Fungura N, Mokrani T, Mateescu C (2015) The realities and economic benefit of the utilization of fuel cells as an alternative source of energy: a review. Energy Sources Part B Econ Plann Policy 10(4):404-411. https://doi.org/ 10.1080/15567249.2011.557684

2. Agarwal U, Jain N (2019) Distributed energy resources and supportive methodologies for their optimal planning under modern distribution network: a review. Technol Econ Smart Grids Sustain Energy 4:3. https://doi.org/10.1007/s40866-019-0060-6

3. Agrawal S, Chourasiya S, Palwalia DK (2017) Hybrid energy management system design with renewable energy sources (fuel cells, PV cells and wind energy): a review. Int J Sci Eng Technol 6(3):174-177. https://doi.org/10.5958/2277-1581.2017.00104.8
4. Ahmadi S, Ghaebi H, Shokri A (2019) A comprehensive Thermodinamic analysis of a novel CHP system based on SOFC and APC cycles. Energy 186:115899-115913. https://doi.org/10.1016/j. energy.2019.115899

5. Akinyele D, Belikov J, Levron Y (2017) Battery storage Technologies for Electrical Applications: impact in stand-alone photovoltaics systems. Energies 10:1760-1799. https://doi.org/10.3390/ en10111760

6. Azizi MA, Brouwer J (2018) Progress in solid oxide fuel cellgas turbine hybrid power systems: system design and analysis, transient operation. Controls Optim Appl Energy 215:237-289. https://doi.org/10.1016/j.apenergy.2018.01.098

7. Barelli L, Bidini G, Gallorini F, Ottaviano A (2011) An energeticexergetic comparison between PEMFC and SOFC-based microCHP systems. Int J Hydrog Energy 36:3206-3214. https://doi.org/ 10.1016/j.ijhydene.2010.11.079

8. Baumann M, Peters JF, Weil M, Grunwald A (2016) CO2 footprint and life cycle costs of electrochemical energy storage for stationary grid applications. Energy Technol 5:1071-1083. https://doi. org/10.1002/ente.201600622

9. Beekelund K (2013) A comparative life cycle assessment of PV solar systems. MSc. Department of Energy and Process Engineering, Norwegian University of Science and Technology, Norway

10. Carvalho NB, Berrêdo Viana N, Muylaert de Araújo MS, Lampreia J, Gomes MSP, Freitas MAV (2020) How likely is Brazil to achieve its NDC commitments in the energy sector? A review on brazilian low-carbon energy perspectives. Renew Sust Energ Rev 133:110343. https://doi.org/10.1016/j.rser.2020.110343

11. Chen X, Wan Z, Gong G, Luo L (2015) Performance analysis of $5 \mathrm{~kW}$ PEMFC-based residential micro-CCHP with absorption chiller. Int J Hydrog Energy 44:10647-10657. https://doi.org/10. 1016/j.ijhydene.2015.06.139 
12. Cruden A, Houghton T, Gair G, Duerr M, Agnew GD, Stewart EM, Lutz A (2008) Fuel cells as distributed generation. Proc Inst Mech Eng Part A J Power Energy 222(7):707-720. https://doi.org/ 10.1243/09576509JPE609

13. Dawood F, Shafiullah GM, Anda M (2020) Stand-alone microgrid with $100 \%$ renewable energy: a case study with hybrid solar PVbattery-hydrogen. Sustainability. 12:2047. https://doi.org/10.3390/ su12052047

14. Di Marcoberardino G, Manzolini G (2017) Investigation of a 5 $\mathrm{kW}$ micro-CHP PEM fuel cell-based system integrated with membrane reactor under diverse EU natural gas quality. Int J Hydrog Energy 42:13988-14002. https://doi.org/10.1016/j.ijhydene.2017. 02.016

15. Du B, Guo Q, Pollard R, Rodriguez D, Smith C, Elter J (2006) PEM fuel cells: status and challenges for commercial stationary power applications. JOM. 58:45-49. https://doi.org/10.1007/ s11837-006-0053-5

16. Ehsan A, Yang Q (2017) Optimal integration and planning of renewable distributed generation in the power distribution networks: a review of analytical techniques. Appl Energy 210:44-59. https://doi.org/10.1016/j.apenergy.2017.10.106

17. EPE, Balanço Energético Nacional (2019) Relatório Síntese / Ano Base 2018. Rio de Janeiro, Brazil, 2019. (in portuguese). https:// www.epe.gov.br/pt/imprensa/noticias/relatorio-sintese-do-balan co-energetico-nacional-2019-ano-base-2018. Accessed 1 Oct 2020

18. Evangelisti S, Tagliaferri C, Brett D, Lettieri P (2016) Life cycle assessment of a polymer electrolyte membrane fuel cell Systems for Passenger Vehicles. J Clean Prod 142:4339-4355. https://doi. org/10.1016/j.jclepro.2016.11.159

19. Francisquini AA (2006) Estimação de Curvas de Carga em Pontos de Consumo e em Transformadores de Distribuição. MSc, Universidade Estadual Paulista, São Paulo, Brazil, (in portuguese)

20. Gerbinet S, Belboom S, Léonard A (2014) Life cycle analysis (LCA) of photovoltaic Pannels: a review. Renew Sust Energ Rev 38:747-753. https://doi.org/10.1016/j.rser.2014.07.043

21. Gomes NC (2019) Avaliação do Potencial de Diversos Combustíveis em Motores de Combustão por Compressão Utilizando a Tecnologia RCCI. Department of Mechanical Engineering, Pontifícia Universidade Católica do Rio de Janeiro, Brazil, (in portuguese)

22. Greener (2019) Strategic Market Study. Distributed Generation Solar PV Market Brazil, $4^{\text {th }}$ Quarter, Brasil. Available at: https:// www.greener.com.br/estudos/. Accessed 1 Oct 2020

23. Greiml M, Traupmann A, Sejkora C, Kriechbaum L, Böckl B, Pichler P, Kienberger T (2020) Modelling and model assessment of grid based Multi-Energy Systems. 29:07-24. https://doi.org/ 10.5278/ijsepm.359

24. IEA (2019), World energy outlook 2019, IEA, Paris - November 2019 Available at: https://www.iea.org/reports/world-energy-outlo ok-2019. Accessed 1 Oct 2020

25. Inac S, Unverdi SO, Midilli A (2019) A parametric study on thermodynamic performance of a SOFC oriented hybrid energy system. Int J Hydrog Energy 44:10043-10058. https://doi.org/10. 1016/j.ijhydene.2019.01.247

26. IRENA (2017) Electricity storage and renewables: costs and markets to 2030, international renewable energy agency, Abu Dhabi. Available at: https://www.irena.org/-/media/Files/IRENA/Agency/ Publication/2017/Oct/IRENA_Electricity_Storage_Costs_2017. Accessed 1 Oct 2020

27. IRENA (2018) Renewable Power Generation Costs in 2017, International Renewable Energy Agency, Abu Dhabi. Available at: https://www.irena.org/-/media/Files/IRENA/Agency/Publication/2018/Jan/IRENA_2017_Power_Costs_2018_summary.pdf?
la=en\&hash=6A74B8D3F7931DEF00AB88BD3B339CAE180 D11C3\#: :text=The $\% 20$ global $\% 20$ weighted $\% 20$ average $\% 20 \mathrm{LCO}$ Ewas\%20around\%20USD\%200.07\%2FkWh. Accessed 1 Oct 2020

28. Jackey RA A simple, effective Lead-acid battery modeling process for electrical system component selection. SAE Technical Paper 2007; 2007-01-0778. https://doi.org/10.4271/2007-01-0778

29. Kairies K Battery storage technology improvements and cost reductions to 2030: A Deep Dive. In: International Renewable Energy Agency Workshop 17 March 2017, Dusseldorf, Germany. Available at: https://www.irena.org/-/media/Files/IRENA/Agency/ Events/2017/Mar/15/2017_Kairies_Battery_Cost_and_Perfo rmance_01.pdf. Accessed 1 Oct 2020

30. Kamal T, Karabacak M, Fernández Ramírez LM, Hassan SZ, Abbas MQ, Khan MA Development of a Monitoring System Based on LabVIEW and MATLAB for a Hybrid Power Supply. Proceedings of the 4th International Conference on Power Generation Systems and Renewable Energy Technologies (PGSRET), 10-12 September 2018, Islamabad, Pakistan

31. Kavlak G, Mcnerney J, Trancik J (2018) Evaluating the causes of cost reduction in photovoltaic modules. Energy Policy 123:700 710. https://doi.org/10.1016/j.enpol.2018.08.015

32. Maclay JD, Brouwer J, Samuelsen GS (2007) Dynamic modeling of hybrid energy storage systems coupled to photovoltaic generation in residential applications. J Power Sources 163:916-925. https://doi.org/10.1016/j.jpowsour.2006.09.086

33. Maclay JD, Brouwer J, Samuelsen GS (2011) Experimental results for hybrid energy storage systems coupled to photovoltaic generation in residential applications. Int J Hydrog Energy 36:1213012140. https://doi.org/10.1016/j.ijhydene.2011.06.089

34. Miranda MM (2012) Fator de Emissão de Gases de Efeito Estufa na Geração de Energia Elétrica no Brasil: Implicações da Aplicação da Avaliação do Ciclo de Vida. MSc. Postgraduate Program in Enrironmental Engineering Sciences, Escola de Engenharia de São Carlos, Universidade de São Paulo, Brazil (in portuguese)

35. Obaid W, Hamid A-K, Ghenai C (2019) Hybrid PEM fuel-cellsolar power system Design for Electric Boat with MPPT system and fuzzy energy management. 2019 International Conference on Communications, Signal Processing, and their Applications (ICCSPA), pp 1-7. https://doi.org/10.1109/ICCSPA.2019.87136 46

36. Ozgirgin E, Devrin Y, Albostan A (2015) Modeling and simulation of a hybrid photovoltaic (PV) module-electrolyzer-PEM fuel cell system for micro-cogeration applications. Int J Hydrog Energy 40:15336-15342. https://doi.org/10.1016/j.ijhydene.2015. 06.122

37. Rekioua D, Bensmail S, Bettar N (2014) Development of hybrid photovoltaic-fuel cell system for stand-alone application. Int J Hydrog Energy 39:1604-1611. https://doi.org/10.1016/j.ijhydene. 2013.03.040

38. Rezk H, Kanagaraj N, Al-Dhaifallah M (2020) Design and sensitivity analysis of hybrid photovoltaic-fuel-cell-battery system to supply a small Community at Saudi NEOM City. Sustainability. 12:3341. https://doi.org/10.3390/su12083341

39. Simpson R, Sastry SK (2013) Basic economic principles and deciding among alternatives. Chemical and Bioprocess Engineering. Springer, New York, pp 325-347

40. Spasova B, Kawamoto D, Takefuji Y (2019) A study of fuel cell scheduling effect on local energy markets with heterogeneous renewable sources. Energies. 12(5):854. https://doi.org/10.3390/ en 12050854

41. Staffell I, Green RJ (2009) Estimating future prices for stationary fuel cells with empirically derived experience curves. Int J Hydrog Energy 34:5617-5628. https://doi.org/10.1016/j.ijhydene.2009.05.075 
42. Staffell I, Scamman D, Abad AV, Balcombe P, Dodds PE, Ekins P, Shah N, Ward KR (2019) The role of hydrogen and fuel cells in the global energy system. Energy Environ Sci 12:463. https:// doi.org/10.1039/c8ee01157e

43. Turkdogan S (2021) Design and optimization of a solely renewable based hybrid energy system for residential electrical load and fuel cell electric vehicle. Eng Sci Technol Int J 24:397-404. https://doi.org/10.1016/j.jestch.2020.08.017

44. U.S. Energy Information Administration Office of Energy Analysis. International Energy Outlook 2019 with projections to 2050 - September 2019 Available at: https://www.eia.gov/outlooks/ieo/ pdf/ieo2019.pdf. Accessed 1 Oct 2020
45. Zakhidov RA, Arifjanov AS (2017) Grid connection Management of Distributed Generators on the basis of renewable energy sources. Appl Solar Energy 53(4):347-353. https://doi.org/10. 3103/S0003701X17040156

46. Zuliani N, Taccani R (2012) Microcogeration system based on HTPEM fuel cell fueled with natural gas: performance analysis. Appl Energy 97:802-808. https://doi.org/10.1016/j.apenergy. 2011.12.089

Publisher's Note Springer Nature remains neutral with regard to jurisdictional claims in published maps and institutional affiliations. 